\title{
Embryonic transcriptome and proteome analyses on hepatic lipid metabolism in chickens divergently selected for abdominal fat content
}

Wei Na, Yuan-Yuan Wu, Peng-Fei Gong, Chun-Yan Wu, Bo-Han Cheng, Yu-Xiang Wang, Ning Wang, Zhi-Qiang Du* and Hui Li

\begin{abstract}
Background: In avian species, liver is the main site of de novo lipogenesis, and hepatic lipid metabolism relates closely to adipose fat deposition. Using our fat and lean chicken lines of striking differences in abdominal fat content, post-hatch lipid metabolism in both liver and adipose tissues has been studied extensively. However, whether molecular discrepancy for hepatic lipid metabolism exists in chicken embryos remains obscure.

Results: We performed transcriptome and proteome profiling on chicken livers at five embryonic stages (E7, E12, E14, E17 and E21) between the fat and lean chicken lines. At each stage, 521, 141, 882, 979 and 169 differentially expressed genes were found by the digital gene expression, respectively, which were significantly enriched in the metabolic, PPAR signaling and fatty acid metabolism pathways. Quantitative proteomics analysis found 20 differentially expressed proteins related to lipid metabolism, PPAR signaling, fat digestion and absorption, and oxidative phosphorylation pathways. Combined analysis showed that genes and proteins related to lipid transport (intestinal fatty acid-binding protein, nucleoside diphosphate kinase, and apolipoprotein A-l), lipid clearance (heat shock protein beta-1) and energy metabolism (NADH dehydrogenase [ubiquinone] 1 beta subcomplex subunit 10 and succinate dehydrogenase flavoprotein subunit) were significantly differentially expressed between the two lines.

Conclusions: For hepatic lipid metabolism at embryonic stages, molecular differences related to lipid transport, lipid clearance and energy metabolism exist between the fat and lean chicken lines, which might contribute to the striking differences of abdominal fat deposition at post-hatch stages.
\end{abstract}

Keywords: Chicken, Embryo, Liver, Lipid metabolism, Digital gene expression, Proteomics

\section{Background}

Broiler is the most efficient meat-producing farm animal, and contributes to alleviating the challenge of food security imposed upon the human society $[1,2]$. For over half a century, commercial broiler has been selected intensively for growth rate and feed efficiency [1]. However, intensive selection on fast growth rate brings along adverse outcomes, such as obesity and related metabolic

\footnotetext{
* Correspondence: zhqdu@neau.edu.cn; lihui@neau.edu.cn

Key Laboratory of Chicken Genetics and Breeding, Ministry of Agriculture, Key Laboratory of Animal Genetics, Breeding and Reproduction, Education Department of Heilongjiang Province, College of Animal Science and Technology, Northeast Agricultural University, Harbin 150030, People's Republic of China
}

syndromes [3]. Excessive fat deposition is undesirable, since it degrades meat quality, decreases feed efficiency, and increases production and health cost [4]. Currently, to reduce fat deposition is still a main objective of commercial broiler selection and breeding program $[1,5]$.

Unlike in mammals, chicken lipogenesis is very limited in the adipose tissue [6], and more than $70 \%$ of de novo fatty acid synthesis takes place in the liver instead [7]. Fatty acids synthesized in the liver are incorporated into triacylglycerols, and secreted as very low-density lipoprotein (VLDL). After hydrolysis by the lipoprotein lipase (LPL), fatty acids released from VLDL penetrate adipocytes, where they are re-esterified and stored as 
triglycerides [8]. Thus, accumulation of triacylglycerols in adipocytes is closely related to lipid metabolism in the liver [9].

The Northeast Agricultural University broiler lines (NEAUHLF) originate from a commercial Arbor Acres grandsire line, and are under divergent selection for abdominal fat content based on abdominal fat percentage (AFP) and plasma VLDL concentration since 1996 [10]. NEAUHLF is a unique animal model to study the molecular mechanism of adipose tissue growth and development. In previous studies, using adipose and liver tissues from the fat and lean chickens at various post-hatch stages $(1,4$ and 7 weeks of age), we have found a number of differentially expressed genes (DEGs) and proteins (DEPs) related to lipid metabolism by the microarray and proteomics methods, such as peroxisome proliferatoractivated receptor gamma $(P P A R \gamma)$, liver basic fatty acids binding protein $(L B F A B P), L P L$, adipocyte fatty acid-binding protein (AFABP), apolipoprotein A-I (ApoA-I), and long-chain acyl-coenzyme A dehydrogenase (ACADL) [10-13].

Embryonic stage now occupies nearly one third of the time to market size for broilers, and is vital to the post-hatch performance of broilers. In order to see if molecular differences of hepatic lipid metabolism existed between our two chicken lines at embryonic stages, we performed digital gene expression profiling and quantitative proteomics on the livers of chicken embryos taken from five embryonic stages, embryonic day 7 (E7), E12, E14, E17, and day 1 after hatch (E21). We identified DEGs and DEPs associated with hepatic lipid metabolism at embryonic stages between the two chicken lines, which could help explain the striking differences of post-hatch abdominal fat content.

\section{Results}

Transcriptome analysis on embryonic livers

Between our broiler lines divergently selected for AFP, significant differences exist since generation 4 (Fig. 1). From the fat and lean chicken lines at generation 14, which had 4.5-fold difference of AFP at 7 weeks of age [14], we collected hepatic tissues from embryos at five important developmental stages (E7, E12, E14, E17 and E21). Total RNAs isolated from hepatic tissues were submitted for sequencing by the digital gene expression profiling technology. For each of the 10 sequenced libraries, an average of 8500 genes (54.8\% of all annotated protein-coding genes) was found, and a large number of novel transcripts were also detected (from 36,569 to 45,021) (Additional file 1).

To identify genes differentially expressed (false discovery rate $\leq 0.001$ and fold changes $\geq 2$ ) and potentially involved in hepatic lipid metabolism, we compared the gene expression profiles between the fat and lean chicken lines. We found 521, 141, 882, 979 and 169 DEGs (Additional files 2, 3, 4, 5 and 6) for the five embryonic stages, respectively (Fig. 2a). Furthermore, after analyzing the number of DEGs among the five different stages, we observed that E17 shared the largest number of DEGs with other embryonic stages (Fig. 2b). However, there were only 6 DEGs common to all five developmental stages, which were involved in cell metabolism, and cell apoptosis pathways, respectively (Fig. $2 \mathrm{~b}$ and Table 1 ).

Gene ontology (GO) and KEGG analysis were performed to analyze biological function of DEGs. DEGs at E7 were enriched in the GO term, the ubiquitin-protein ligase activity. No GO term was found at E12. At E14, the highly enriched GO terms were related to biological processes, such as translation, metabolic process, catabolic process, and RNA binding. At E17, GO terms, such

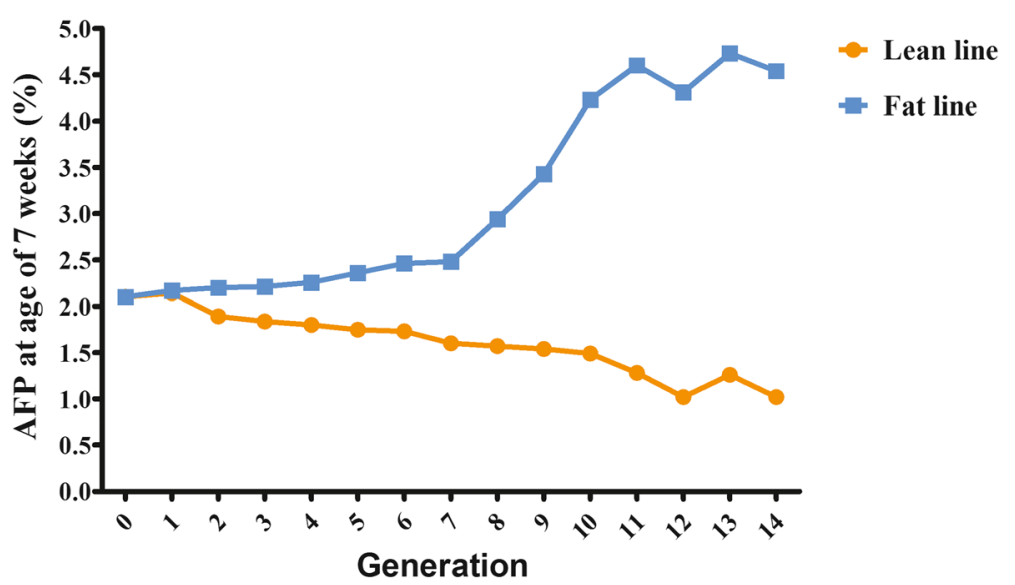

Fig. 1 Divergent selection on abdominal fat percentage (AFP) at 7 weeks of age. Starting from generation 4, significant differences existed between the two chicken lines 


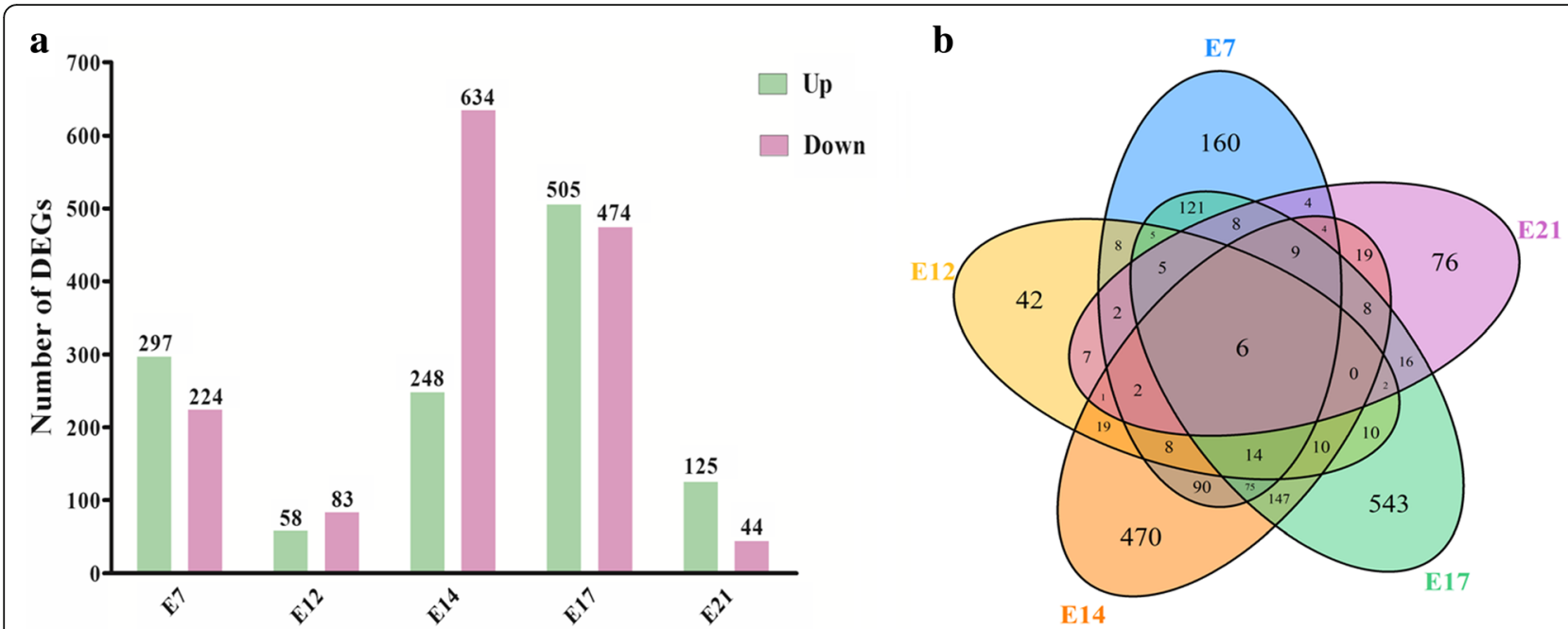

Fig. 2 Differentially expressed genes (DEGs) identified for hepatic tissues in chicken embryos. a Number of DEGs at five developmental stages between the fat and lean lines. Up and Down, up- and down-regulated DEGs in the fat line; $\mathbf{b}$ Venn diagram for DEGs identified

as carboxylic acid metabolic process, oxoacid metabolic process, cellular ketone metabolic process, oxidoreductase activity, and catalytic activity, were enriched. The GO term metallopeptidase activity was enriched for E21 (Fig. 3).

Similar to GO analysis, no significant signaling pathway was found for E12 in KEGG analysis (Fig. 4a). While for the remaining 4 embryonic stages (E7, E14, E17, and E21), a common signaling pathway, the metabolic pathway, was found. At E14, pathways mainly related to aminoacyltRNA biosynthesis, ribosome, spliceosome and lysosome were enriched. A large number of signaling pathways were enriched for DEGs at E17, including those directly related to lipid metabolism, such as fatty acid metabolism and biosynthesis, PPAR signaling pathway, and glycolysis (Fig. 4b).
At E21, the amino acid metabolism (tryptophan metabolism and lysine degradation) pathway was enriched.

We validated the digital gene expression results of 12 DEGs (a total of 21 DEGs were selected from 6 common DEGs and top 3 DEGs of each embryonic stage, and 9 of them were duplicated) by qRT-PCR assays. The qRT-PCR results of 2 genes, LOC77109 and keratin 75 (KRT75), were not analyzed because of their low expression levels $(\mathrm{Ct}>32)$. Otherwise, poor reproducibility and unreliable results could be obtained. For the remaining 10 genes, we found out that 4 genes (APOA4, LOC769366, HSPA9 and $B A P 1)$ at E7, 2 genes (BAP1 and LOC769366) at E12, 2 genes (LOC769366 and ALDH7A1) at E14, 4 genes (LOC769366, BAP1, XPO5 and ALDH7A1) at E17, and 3 genes (TMEM79, LOC769366 and HSPA9) at E21, were

Table 1 Common DEGs to all five embryonic stages

\begin{tabular}{|c|c|c|c|c|}
\hline Gene & $\begin{array}{l}\text { Average fold-change } \\
\text { (Log2 ratio) }^{\mathrm{a}}\end{array}$ & $\begin{array}{l}\text { GO: Cell } \\
\text { component }\end{array}$ & $\begin{array}{l}\text { GO: Molecular } \\
\text { function }\end{array}$ & $\begin{array}{l}\text { GO: Biological } \\
\text { processes }\end{array}$ \\
\hline HSPA9 & +2.58 & mitochondrial matrix & protein binding & $\begin{array}{l}\text { cellular protein metabolic } \\
\text { process, protein targeting, } \\
\text { negative regulation of apoptosis }\end{array}$ \\
\hline LOC777109 & +9.89 & membrane, I band & $\begin{array}{l}\text { cytoskeletal protein } \\
\text { binding }\end{array}$ & $\begin{array}{l}\text { striated muscle cell } \\
\text { development }\end{array}$ \\
\hline LOC769366 & +9.30 & NA & NA & NA \\
\hline BAP1 & -7.39 & PcG protein complex & $\begin{array}{l}\text { binding, thiolester hydrolase activity, } \\
\text { small conjugating protein-specific } \\
\text { protease activity }\end{array}$ & $\begin{array}{l}\text { cell growth, cell cycle, } \\
\text { modification-dependent } \\
\text { protein catabolic process, } \\
\text { cell proliferation }\end{array}$ \\
\hline XPO5 & -1.72 & nuclear lumen & RNA binding & $\begin{array}{l}\text { protein targeting, } \\
\text { gene silencing }\end{array}$ \\
\hline ALDHTA1 & -1.40 & $\begin{array}{l}\text { intracellular membrane-bounded } \\
\text { organelle, cytoplasmic part }\end{array}$ & $\begin{array}{l}\text { aldehyde dehydrogenase } \\
{[\mathrm{NAD}(\mathrm{P})+] \text { activity }}\end{array}$ & $\begin{array}{l}\text { cellular metabolic process, } \\
\text { sensory perception of } \\
\text { mechanical stimulus }\end{array}$ \\
\hline
\end{tabular}




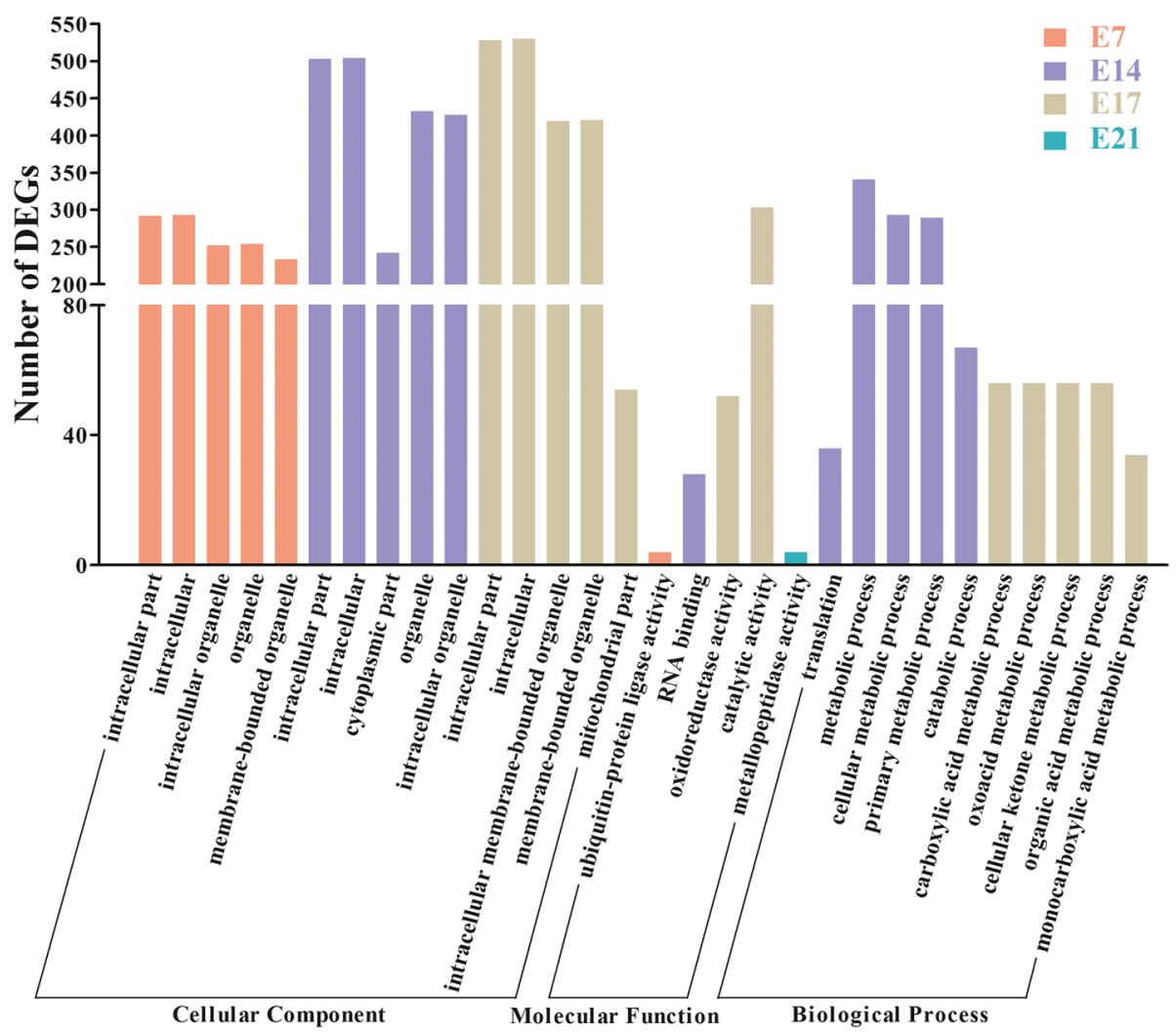

Fig. $3 \mathrm{GO}$ analysis of DEGs at different embryonic stages. Significantly enriched GO terms in the biological process, cellular component and molecular function (top five GO terms) categories, respectively $(P<0.05)$. $y$-axis, the number of DEGs

validated to be significant or approximately significant, respectively (Fig. 5b). Moreover, APOA4 at E7, HSPA9 at E7 and E21, BAP1 at E12 and E17, ALDH7A1 at E14 and E17, XPO5 at E17, TMEM79 at E21 had similar trends for the digital gene expression and qRT-PCR results, whereas $L O C 769366$ at all five time points and BAP1 at E7 had opposite trends. In all, our qRT-PCR results were consistent with the digital gene expression results (correlation coefficient $r=0.73$ ).

\section{Comparative proteomics on embryonic hepatic tissues}

Quantitative proteomics data were generated from 15 high-quality and reproducible 2-D DIGE maps (Additional file 7). On each gel, about 2000 protein spots were detected. The isoelectric points of most proteins focused on 4 to 10 , while molecular weights were distributed from 5 to $100 \mathrm{kDa}$.

We compared protein profiles between the fat and lean lines at each time point to find key proteins related to lipid metabolism. We found 14 (protein spots $3,4,9,10,12,21$, $23,27,33,35,40,47,50,58$ ), 5 (protein spots 21, 24, 25, 27,33 ), 4 (protein spots $6,7,8,14$ ), 2 (protein spots 31 , $57)$ and 1 (protein spot 40) differentially expressed protein spots $(P<0.05$ and fold changes $\geq 1.5)$ for the five time points (E7, E12, E14, E17 and E21), respectively (Figs. 6 and 7). Among these differentially expressed protein spots, 3 protein spots $(21,27,33)$ were common to E7 and E12, and the protein spot 40 was common to E7 and E21. At E7, differentially expressed protein spots $3,4,9,10,12,23$, 40 and $21,27,33,35,47,50,58$ were up-regulated and down-regulated in the fat line, respectively. At E12 (protein spots 21, 24, 25, 27, 33) (Fig. 7) and E14 (protein spots $6,7,8,14)$, signal intensities of these differentially expressed protein spots in the lean line was obviously stronger than those in the fat line. At E17, the differentially expressed protein spot 31 was down-regulated, whereas spot 57 was up-regulated in the fat line. At E21, differentially expressed protein spot 40 had higher expression abundance in the fat line.

A total of 26 differentially expressed protein spots were found at the five embryonic stages between the fat and lean lines, and after removing the 4 protein spots that repeated multiple times, 22 differentially expressed protein spots were identified by MALDI-TOF-MS. Except that 2 protein spots $(4,6)$ could not be identified, the remaining 20 protein spots matched to 17 proteins in the chicken protein database, and to 3 other proteins in protein databases of other species (Table 2).

These 17 proteins matching the chicken protein database included 3 proteins which had been identified 


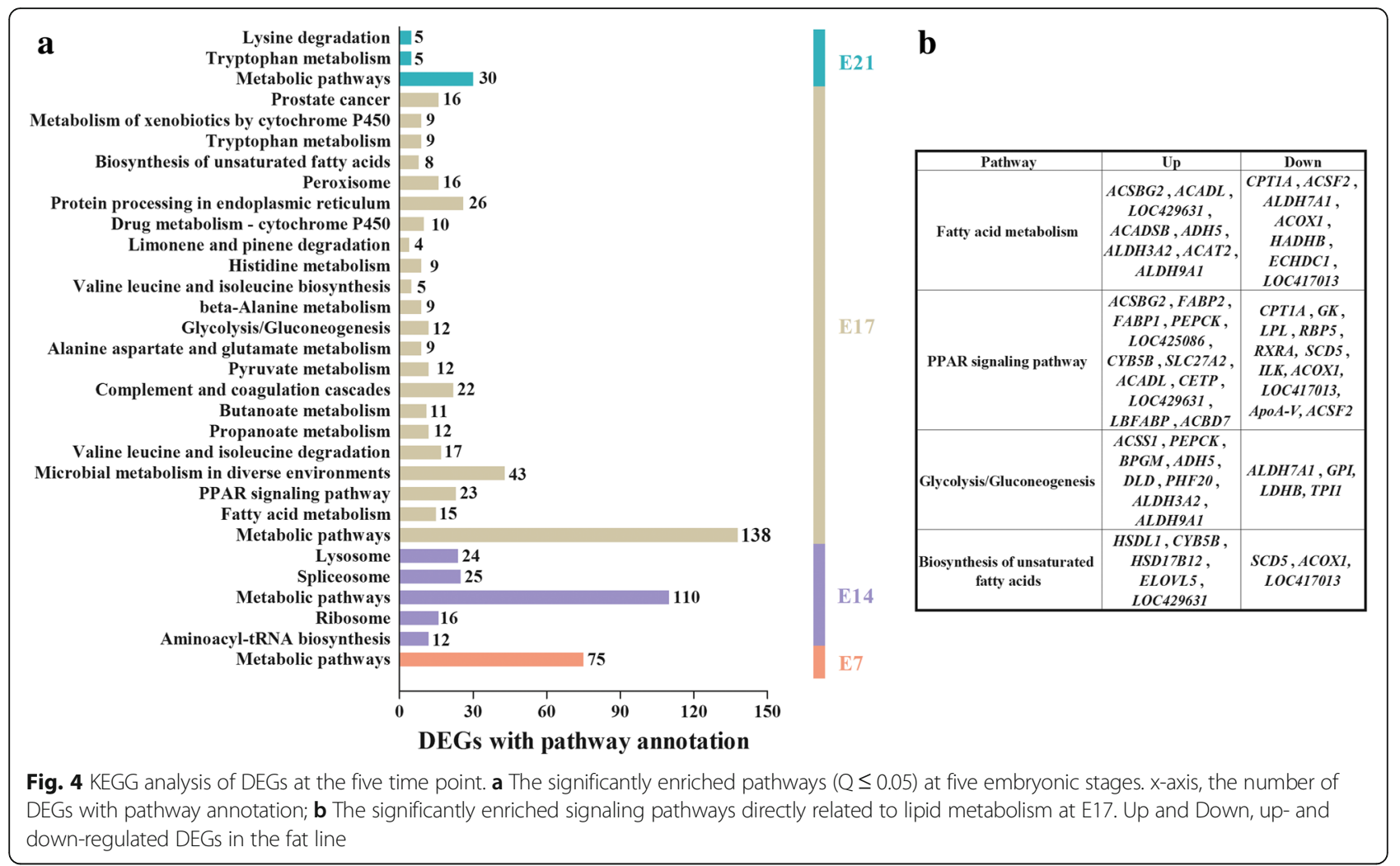

twice, the alpha-fetoprotein (protein spots 7 and 8), ovalbumin (OVAL) (protein spots 24 and 25) and nucleoside diphosphate kinase (NDK) (protein spots 40 and 58 ), possibly due to different protein isoforms or posttranslational modifications (Table 2). For the 14 different DEPs, after GO analysis, 9 of them could be classified into 3 categories with regard to the molecular function: catalytic activity (67\%), binding (22\%), and transporter activity (11\%). However, for the remaining 5 , we could not find any hits related to the molcular function. These DEPs were mainly involved in the PPAR signaling pathway, citrate cycle (TCA cycle), fat digestion and absorption, oxidative phosphorylation, aminoacyl-tRNA biosynthesis and MAPK signaling pathways.

\section{Integrated analysis on transcriptome and proteome data}

For the 14 DEPs identified by the comparative proteomics, 2 of them, alpha-fetoprotein and OVAL, had no data in the digital gene expression experiment. The transcriptional abundances of the remaining 12 DEPs were validated by $\mathrm{qRT}-\mathrm{PCR}$, at the same time points when significant differences of protein abundances were found. However, only were three genes, lysyl-tRNA synthetase (KARS), tyrosyl-tRNA synthetase (YARS) and intestinal fatty acid-binding protein ( $F A B P 2)$, validated to be significantly differentially expressed at E7 and E17, respectively (Fig. 8). When comparing the digital gene expression and qRT-PCR results, KARS and YARS had opposite expression trends at E7, and FABP2 had a similar expression trend at E17. In addition, similar expression patterns to their digital gene expression results were obtained for 5 genes, succinate dehydrogenase [ubiquinone] flavoprotein subunit $(S D H A)$ at E7, thioredoxin domain-containing protein 5 (TXNDC5) at E7, sulfotransferase $(S U L T)$ at E7 and E12, inosine triphosphatase (ITPA) at E7, and ApoA-I at E17. By contrast, opposite expression levels were found for 4 other genes, NADH dehydrogenase [ubiquinone] 1 beta subcomplex subunit 10 (NDUFB10) at E7, heat shock protein beta-1 (HSPB1) at E7 and E12, coronin-1C (CORO1C) at E14, and $N D K$ at E7 and E21. Furthermore, a general correlation analyses showed that digital gene expression and qRT-PCR results were consistent with each other (correlation coefficients $r=0.86$ and 0.84 for the lean and fat lines, respectively).

To validate the proteomics results, the western blot experiment was performed for ApoA-I and FABP2. We selected these two proteins, based on the facts that ApoA-I antibody is prepared in the lab and ready-to-use, FABP2 antibody is commercially available and the antigenic epitope of the commercial FABP2 antibody is relatively conserved ( $72 \%$ similarity to human). Western blot results confirmed that ApoA-I and FABP2 had significantly differential abundance at E17 (Fig. 9a, b).

Furthermore, joint analysis on mRNA and protein expression data based on qRT-PCR results and proteomics 

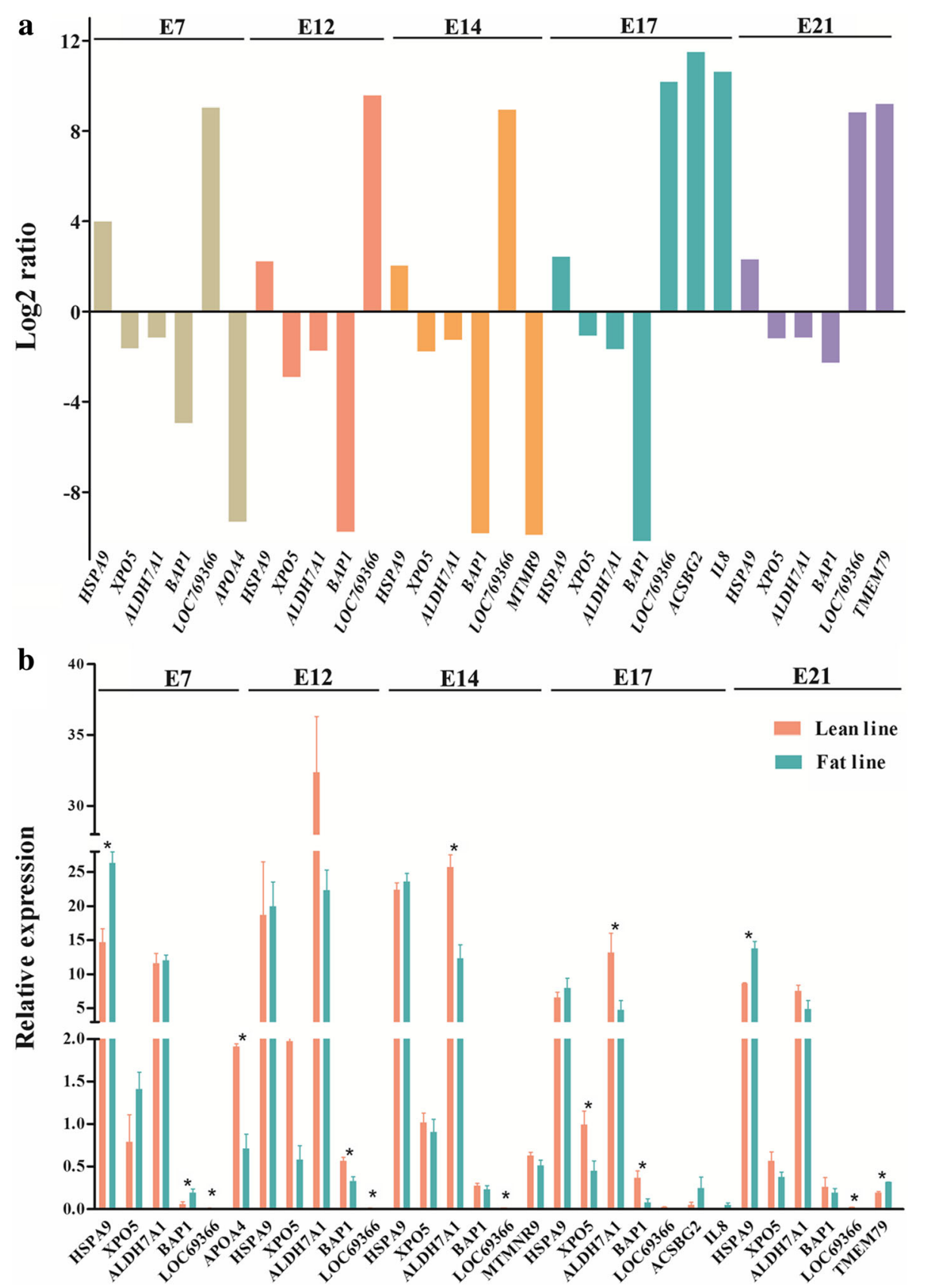

Fig. 5 Validation of DEGs by qRT-PCR. a 12 DEGs identified by digital gene expression. Y-axis, log2 (fold change of gene expression levels of the fat line vs. the lean line); $\mathbf{b}$ qRT-PCR results of 12 DEGs in both chicken lines. *, significant or approximately significant $(P<0.05)$

results was performed, to see if the mRNA and protein abundance levels of 12 DEPs were consistent with each other. The 12 DEPs were classified into two main groups. Group I contained 3 proteins significantly differentially expressed at both transcriptional and protein expression levels, which could be divided into two subgroups. Subgroup 1 included 2 proteins, in which YARS and FABP2 were significantly higher in the fat birds at E7 and E17. In contrast, in subgroup 2, the protein level of KARS was opposite to its transcriptional level at E7. In Group II, 9 DEPs were not significantly differentially expressed at the transcriptional levels, which could also be classified into 2 subgroups. Subgroup 1 has 6 DEPs with well-matched tendency of transcriptional levels, including TXNDC5, SULT, ITPA, NDUFB10, NDK (protein spot 58) at E7, HSPB1 at E12. Subgroup 2 has 6 DEPs with opposite transcriptional trends, including SDHA, HSPB1 at E7, SULT at E12, 


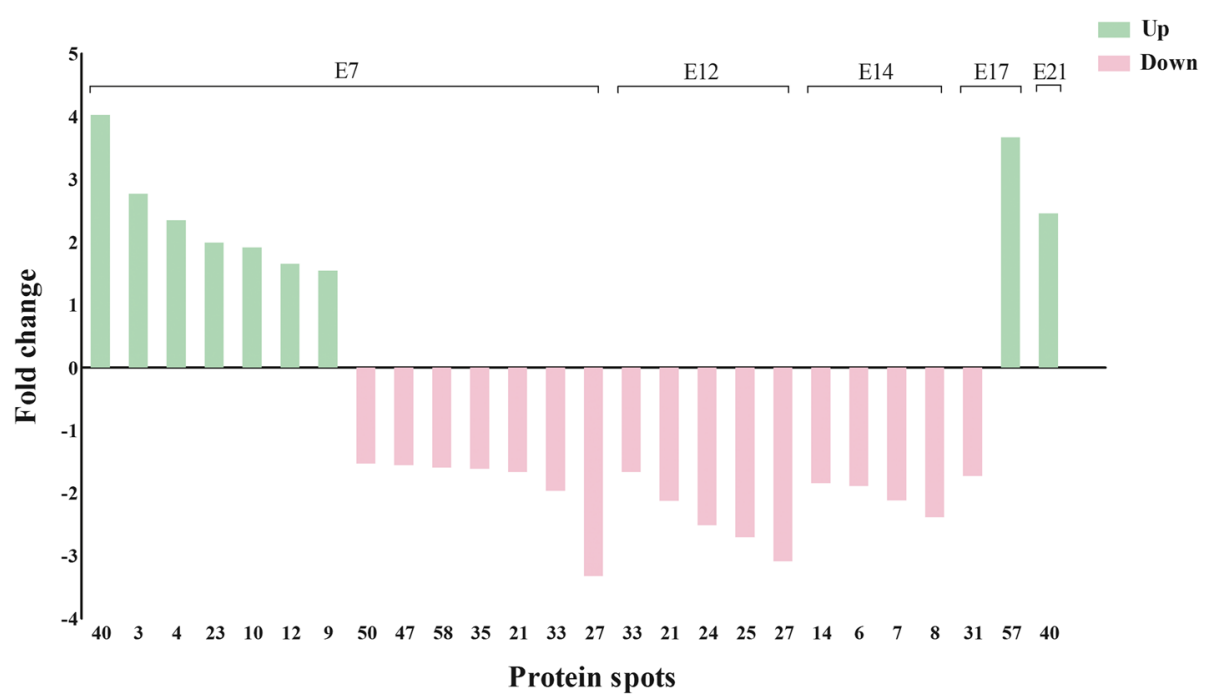

Fig. 6 A total of 26 protein spots analyzed between the two lines at five time points. $x$-axis, differentially expressed protein spots. $y$-axis, fold change-Ratio (Fat/Lean). + and -, up- and down-regulated in the fat line

CORO1C at E14, ApoA-I at E17, NDK (protein spot 40) at E7 at E21. Subgroups 1 and 2 shared three genes, SULT, HSPB1 and NDK, showing different patterns of transcriptional abundances at different embryonic stages (Table 3).

\section{Discussion}

Nowadays, to reduce fat deposition is still an important goal for commercial chicken breeding program [5]. In avian species, the liver is the main site of de novo fatty acid synthesis [7], while the adipose tissue serves mainly as a storage tissue $[6,15]$. Accumulation of triacylglycerols in adipose tissue is directly related with hepatic lipogenesis [9]. Using NEAUHLF, a suitable animal model to study the molecular mechanism of adipose tissue growth and development, we previously found genes and molecular pathways important for hepatic lipid metabolism (PPARy, LBFABP, ApoA-I, AFABP and glycolmetabolism) in the liver and adipose tissues at 1, 4 and 7 weeks of age by microarray and proteomics analyses [10-13]. However, whether there are differences on hepatic lipid metabolism between the two lines in embryonic stages remains unknown. In the current study, we compared transcriptome and proteome profiling on hepatic tissues sampled from 5 different embryonic stages between the two lines. Integrated mRNA and protein expression data showed that 8 DEPs (2 and 6 in subgroups 1 of Group I and II, respectively), YARS, TXNDC5, SULT, ITPA, NDUFB10, NDK (protein spot 58) at E7, HSPB1 at E12, and FABP2 at E17, had similar trend of
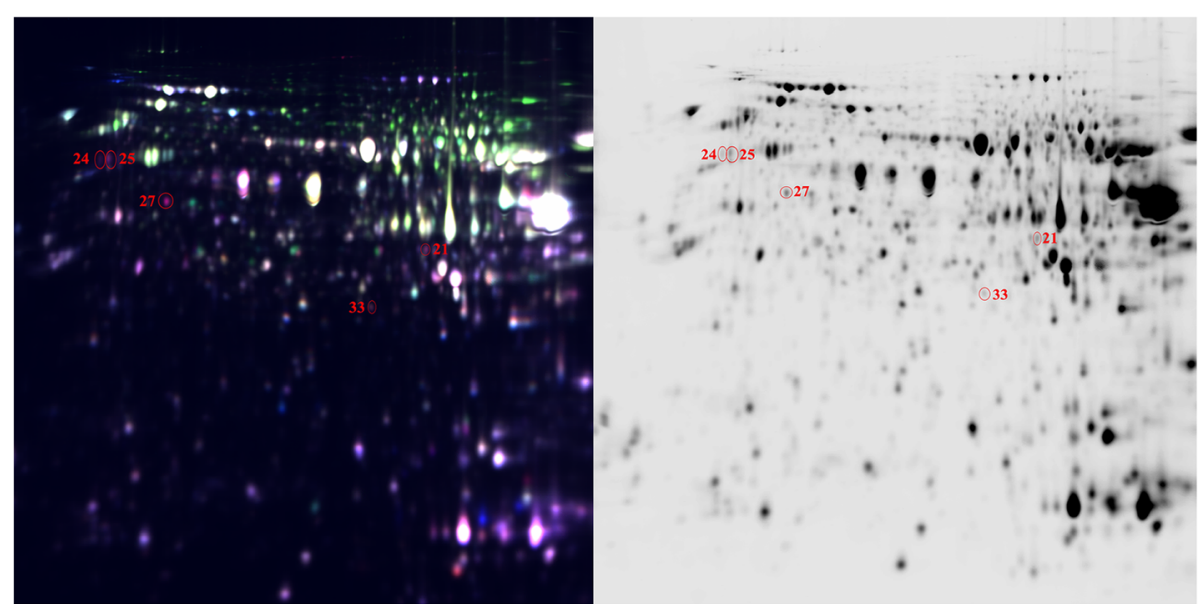

Fig. 7 Representative 2D DIGE images. At E12, 5 differentially expressed protein spots were identified 
Table 2 Features of the 20 differentially expressed proteins identified by MALDI-TOF-MS

\begin{tabular}{|c|c|c|c|c|c|c|c|c|c|}
\hline Stage & $\begin{array}{l}\text { Protein } \\
\text { spot } \\
\text { No. }\end{array}$ & $\begin{array}{l}\text { Fold } \\
\text { change-ratio } \\
\text { (Fat/Lean) }\end{array}$ & $\begin{array}{l}\text { Accession } \\
\text { No. } \\
\text { (NCBInr/UniProt) }\end{array}$ & $\begin{array}{l}\text { Protein } \\
\text { name }\end{array}$ & $\begin{array}{l}\text { Molecular } \\
\text { weight } \\
(\mathrm{kDa})\end{array}$ & $\mathrm{pl}$ & $\begin{array}{l}\text { Protein } \\
\text { score }\end{array}$ & $\begin{array}{l}\text { Protein } \\
\text { score } \\
\text { C.I.\% }\end{array}$ & $\begin{array}{l}\text { Subcellular } \\
\text { localization }\end{array}$ \\
\hline \multirow[t]{14}{*}{ E7 } & 3 & 2.77 & gi|71895483 & $\begin{array}{l}\text { lysyl-tRNA } \\
\text { synthetase }\end{array}$ & $68,330.4$ & 5.89 & 271 & 100 & $\begin{array}{l}\text { Cytoplasm; } \\
\text { Mitochondrion }\end{array}$ \\
\hline & 4 & 2.35 & $\begin{array}{l}\text { Unknown } \\
\text { protein }\end{array}$ & & & & & & \\
\hline & 9 & 1.54 & Q9YHT1 & $\begin{array}{l}\text { Succinate dehydrogenase } \\
\text { [ubiquinone] flavoprotein } \\
\text { subunit, mitochondrial }\end{array}$ & $74,024.6$ & 6.65 & 63 & 94.987 & Mitochondrion \\
\hline & 10 & 1.91 & Q5ZJ08 & $\begin{array}{l}\text { Tyrosyl-tRNA synthetase, } \\
\text { cytoplasmic }\end{array}$ & $59,703.1$ & 6.24 & 76 & 99.743 & Cytoplasm \\
\hline & $12^{\mathrm{a}}$ & 1.65 & gi|326927880 & $\begin{array}{l}\text { PREDICTED: transketolase-like } \\
\text { [Meleagris gallopavo] }\end{array}$ & $87,487.4$ & 8.17 & 125 & 100 & \\
\hline & $21^{\mathrm{a}}$ & -1.67 & gi|326936041 & $\begin{array}{l}\text { PREDICTED: delta(3,5)-Delta } \\
\text { (2,4)-dienoyl-CoA isomerase, } \\
\text { mitochondrial-like, partial } \\
\text { [Meleagris gallopavo] }\end{array}$ & $16,841.6$ & 6.9 & 99 & 99.971 & \\
\hline & 23 & 1.99 & gi|57530789 & $\begin{array}{l}\text { Thioredoxin domain-containing } \\
\text { protein } 5\end{array}$ & $47,249.1$ & 5.61 & 167 & 100 & \\
\hline & 27 & -3.33 & gi|45384226 & Sulfotransferase & $36,333.5$ & 5.89 & 129 & 100 & \\
\hline & 33 & -1.97 & gi|45384222 & $\begin{array}{l}\text { Heat shock } \\
\text { protein beta-1 }\end{array}$ & 21,715 & 5.77 & 135 & 100 & $\begin{array}{l}\text { Cytoplasm; } \\
\text { Nucleus; } \\
\text { Mitochondrion }\end{array}$ \\
\hline & $35^{\mathrm{a}}$ & -1.62 & gi|109032822 & $\begin{array}{l}\text { PREDICTED: transcription } \\
\text { factor BTF3-like } \\
\text { [Macaca mulatta] }\end{array}$ & $17,669.1$ & 5.74 & 181 & 100 & \\
\hline & 40 & 4.02 & O57535 & Nucleoside diphosphate kinase & $17,447.9$ & 7.72 & 75 & 99.661 & $\begin{array}{l}\text { Cytoplasm; } \\
\text { Cell membrane }\end{array}$ \\
\hline & 47 & -1.56 & gi|50751047 & $\begin{array}{l}\text { PREDICTED: inosine } \\
\text { triphosphate } \\
\text { pyrophosphatase }\end{array}$ & $22,533.4$ & 5.8 & 142 & 100 & \\
\hline & 50 & -1.53 & gi|50755667 & $\begin{array}{l}\text { PREDICTED: NADH } \\
\text { dehydrogenase } \\
\text { [ubiquinone] } 1 \text { beta } \\
\text { subcomplex subunit } 10\end{array}$ & $20,769.2$ & 5.98 & 181 & 100 & \\
\hline & 58 & -1.6 & O57535 & $\begin{array}{l}\text { Nucleoside diphosphate } \\
\text { kinase }\end{array}$ & $17,447.9$ & 7.72 & 123 & 100 & $\begin{array}{l}\text { Cytoplasm; } \\
\text { Cell membrane }\end{array}$ \\
\hline \multirow[t]{5}{*}{ E12 } & $21^{\mathrm{a}}$ & -2.13 & gi|326936041 & $\begin{array}{l}\text { PREDICTED: delta(3,5)-Delta } \\
\text { (2,4)-dienoyl-CoA isomerase, } \\
\text { mitochondrial-like, partial } \\
\text { [Meleagris gallopavo] }\end{array}$ & $16,841.6$ & 6.9 & 99 & 99.971 & \\
\hline & 24 & -2.52 & gi|129293 & Ovalbumin & $43,195.6$ & 5.19 & 197 & 100 & $\begin{array}{l}\text { Extracellular } \\
\text { region }\end{array}$ \\
\hline & 25 & -2.71 & gi|129293 & Ovalbumin & $43,195.6$ & 5.19 & 370 & 100 & Extracellular region \\
\hline & 27 & -3.09 & gi|45384226 & Sulfotransferase & $36,333.5$ & 5.89 & 129 & 100 & \\
\hline & 33 & -1.67 & gi|45384222 & $\begin{array}{l}\text { Heat shock protein } \\
\text { beta-1 }\end{array}$ & 21,715 & 5.77 & 135 & 100 & $\begin{array}{l}\text { Cytoplasm; Nucleus; } \\
\text { Mitochondrion }\end{array}$ \\
\hline \multirow[t]{4}{*}{ E14 } & 6 & -1.89 & $\begin{array}{l}\text { Unknown } \\
\text { protein }\end{array}$ & & & & & & \\
\hline & 7 & -2.12 & P84407 & Alpha-fetoprotein & $72,857.6$ & 6.26 & 66 & 97.655 & Secreted \\
\hline & 8 & -2.39 & P84407 & Alpha-fetoprotein & $72,857.6$ & 6.26 & 71 & 99.187 & Secreted \\
\hline & 14 & -1.85 & gi|86129440 & Coronin-1C & $53,744.3$ & 6,22 & 109 & 99.997 & Intracellular \\
\hline
\end{tabular}


Table 2 Features of the 20 differentially expressed proteins identified by MALDI-TOF-MS (Continued)

\begin{tabular}{|c|c|c|c|c|c|c|c|c|c|}
\hline Stage & $\begin{array}{l}\text { Protein } \\
\text { spot } \\
\text { No. } \\
\end{array}$ & $\begin{array}{l}\text { Fold } \\
\text { change-ratio } \\
\text { (Fat/Lean) }\end{array}$ & $\begin{array}{l}\text { Accession } \\
\text { No. } \\
\text { (NCBInr/UniProt) }\end{array}$ & $\begin{array}{l}\text { Protein } \\
\text { name }\end{array}$ & $\begin{array}{l}\text { Molecular } \\
\text { weight } \\
(\mathrm{kDa})\end{array}$ & $\mathrm{pl}$ & $\begin{array}{l}\text { Protein } \\
\text { score }\end{array}$ & $\begin{array}{l}\text { Protein } \\
\text { score } \\
\text { C.I.\% } \\
\end{array}$ & $\begin{array}{l}\text { Subcellular } \\
\text { localization }\end{array}$ \\
\hline \multirow[t]{2}{*}{$\overline{E 17}$} & 31 & -1.73 & P08250 & Apolipoprotein A-I & $30,661.1$ & 5.58 & 72 & 99.292 & Secreted \\
\hline & 57 & 3.67 & gi|56119000 & $\begin{array}{l}\text { Intestinal fatty } \\
\text { acid-binding protein }\end{array}$ & $15,079.7$ & 6.62 & 247 & 100 & $\begin{array}{l}\text { Intracellular } \\
\text { part }\end{array}$ \\
\hline E21 & 40 & 2.46 & O57535 & $\begin{array}{l}\text { Nucleoside diphosphate } \\
\text { kinase }\end{array}$ & $17,447.9$ & 7.72 & 75 & 99.661 & $\begin{array}{l}\text { Cytoplasm; } \\
\text { Cell membrane }\end{array}$ \\
\hline
\end{tabular}

${ }^{a}$ represents proteins matched to other databases. Unknown protein indicates protein spots could not be identified

transcriptional levels. However, 7 DEPs (1 and 6 in subgroups 2 of Group I and Group II, respectively), KARS, SDHA, HSPB1 at E7, SULT at E12, CORO1C at E14, ApoA-I at E17, and NDK (protein spot 40) at E7 at E21, had opposite transcriptional trends. Inconsistency between mRNA and protein expression levels probably comes from a variety of factors involved in the regulation of mRNA and protein abundances, such as (post-) transcriptional and (post-) translational regulation, protein modification, protein-protein interaction, and other regulatory mechanisms as well [16]. Among these 12 DEPs, FABP2, NDK and ApoA-I were involved in lipid transport; HSPB1 was related to lipid clearance; SULT and TXNDC5 could participate in hepatic lipid metabolism through PPARy and apolipoprotein B (ApoB); SDHA and NDUFB10 were involved in energy metabolism. However, for KARS, YARS, ITPA and CORO1C, no reports on their direct relationship with lipid metabolism are available.

Proteins related to lipid transport, FABP2, NDK and ApoA-I, were found to be differentially expressed between the two lines in the present study. FABP2, also known as intestinal FABP (I-FABP), had higher protein and mRNA abundances in the fat broilers at stages of rapid growth and development (E12, E14, E17 and E21) found by both transcriptome and proteome analyses,

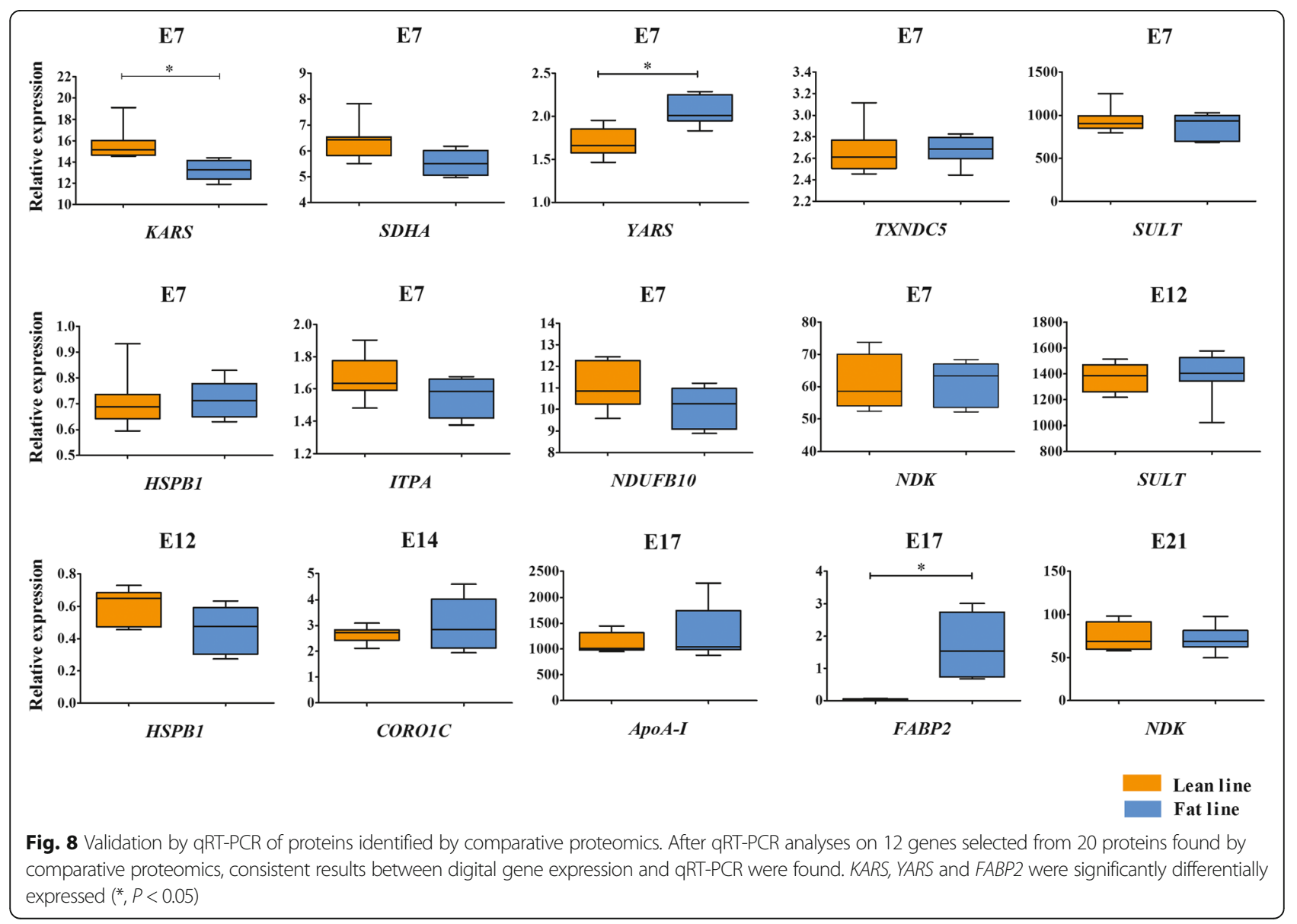




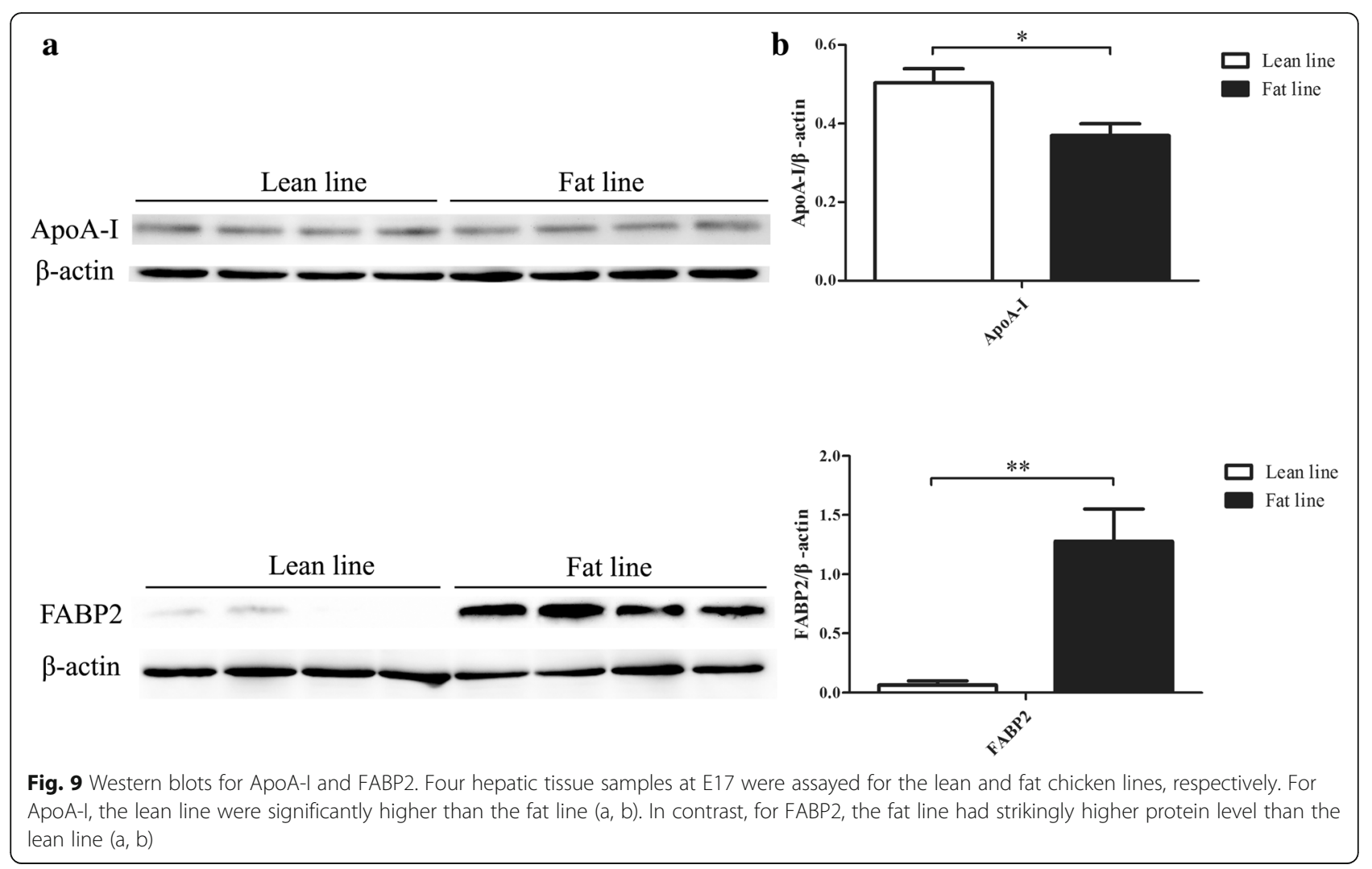

which were also validated to be significantly differentially expressed between the two lines at E17 by western blot and qRT-PCR. FABP2 is involved in lipid metabolism, especially in the uptake, intracellular metabolism and transport of long chain fatty acids [17, 18]. FABP2 may also influence mitochondrial fatty acid oxidation and free cholesterol transport by regulating gene expression and interaction with nuclear receptors [19]. The higher expression level of FABP2 in the fat birds may imply that the fat birds have stronger capacity of lipid transport.

In the present study, mass spectrometry results showed NDK had two isoforms (protein spots 40 and 58). The abundance of protein spot 40 in the fat line was significantly higher than that in the lean line at E7 and E21, and the transcriptional level of NDK was higher in the lean line compared to the fat line at E7 and E21. However, for protein spot 58 at E7, its mRNA and protein abundance was down-regulated in the fat birds. $\mathrm{Hu}$ man studies also indicate that NDK have two isoforms. Though the two isoforms are closely related in amino acid sequences ( $88 \%$ identity), they display significant differences in cellular functions [20]. NDK catalyzes phosphoryl transfer from a nucleoside triphosphate to a nucleoside diphosphate, and functions in the metabolic pathway [21]. NDK regulates synaptic vesicle internalization, where the dynamin GTPase is required to function [22], and is indispensable in energy metabolism in development [23]. Recently, it was found that NDK is a lipid-dependent mitochondrial switch in both phosphortransfer and inter-membrane cardiolipin transfer, which relates to apoptotic signaling and other putative functions, potentially important in lipid metabolism [24, 25].

In addition, for ApoA-I that is also involved in lipid transport, we found that the lean birds had a significantly higher ApoA-I protein abundance at E17. However, no transcriptional difference for ApoA-I in the embryonic liver was found between the fat and lean broilers at E17, suggesting the ApoA-I may be regulated at the translational level. We previously examined ApoA-I and its association with fat deposition using genetics, gene expression and proteomics methods in adipose tissues $[12,13]$. ApoA-I is a major component of high-density lipoprotein (HDL) in the plasma [26], and can promote cholesterol efflux from peripheral tissues to the liver to keep body cholesterol in balance [27]. ApoA-I can not only function as a key lipoprotein to transport cholesterol, but can also inhibit fatty acid synthesis in mice [28]. Thus, we speculate that ApoA-I can influence embryonic liver lipid metabolism, and contribute to the striking differences of abdominal fat deposition between the fat and lean chicken lines.

HSPB1 could be related to lipid clearance, and protein levels were significantly higher in the lean birds at E7 and E12 as revealed by quantitative proteomics. At E12, 
Table 3 Joint analyses on differentially expressed genes and proteins in qRT-PCR and comparative proteomics

\begin{tabular}{|c|c|c|c|c|c|c|c|}
\hline Group & Stage & $\begin{array}{l}\text { Protein } \\
\text { name }\end{array}$ & $\begin{array}{l}\text { Gene } \\
\text { name }\end{array}$ & $\begin{array}{l}\text { DEPs in } \\
\text { comparative } \\
\text { proteomics }\end{array}$ & $\begin{array}{l}\text { Differential } \\
\text { expression genes } \\
\text { in qRT-PCR } \\
\end{array}$ & $\begin{array}{l}\text { Molecular } \\
\text { function }\end{array}$ & $\begin{array}{l}\text { Biological } \\
\text { process }\end{array}$ \\
\hline \multirow[t]{2}{*}{ Group I-subgroup 1} & E7 & $\begin{array}{l}\text { Tyrosyl-tRNA } \\
\text { synthetase, cytoplasmic }\end{array}$ & YARS & $\begin{array}{l}\text { Y } \\
\text { (Fat }>\text { Lean) }\end{array}$ & $Y($ Fat > Lean) & $\begin{array}{l}\text { Aminoacyl-tRNA } \\
\text { ligase activity }\end{array}$ & $\begin{array}{l}\text { Amino acid } \\
\text { synthesis }\end{array}$ \\
\hline & E17 & $\begin{array}{l}\text { Intestinal fatty } \\
\text { acid-binding protein }\end{array}$ & FABP2 & $\begin{array}{l}\text { Y } \\
\text { (Fat }>\text { Lean) }\end{array}$ & $Y($ Fat > Lean $)$ & $\begin{array}{l}\text { Lipid binding, } \\
\text { transporter activity }\end{array}$ & Lipid transport \\
\hline Group I-subgroup 2 & E7 & lysyl-tRNA synthetase & KARS & $\begin{array}{l}\text { Y } \\
\text { (Fat }>\text { Lean) }\end{array}$ & $Y($ Lean > Fat $)$ & $\begin{array}{l}\text { Aminoacyl-tRNA } \\
\text { ligase activity }\end{array}$ & $\begin{array}{l}\text { Amino acid } \\
\text { synthesis }\end{array}$ \\
\hline \multirow[t]{6}{*}{ Group II-subgroup 1} & E7 & $\begin{array}{l}\text { Thioredoxin } \\
\text { domain-containing } \\
\text { protein } 5\end{array}$ & TXNDC5 & Y (Fat > Lean) & N (Fat > Lean) & $\begin{array}{l}\text { Disulfide } \\
\text { oxidoreductase activity }\end{array}$ & $\begin{array}{l}\text { Protein } \\
\text { folding }\end{array}$ \\
\hline & E7 & Sulfotransferase & SULT & $\begin{array}{l}\text { Y } \\
\text { (Lean > Fat) }\end{array}$ & N (Lean > Fat) & $\begin{array}{l}\text { Sulfotransferase } \\
\text { activity, transferase activity }\end{array}$ & $\begin{array}{l}\text { Sulfuryl } \\
\text { transfer }\end{array}$ \\
\hline & E7 & $\begin{array}{l}\text { PREDICTED: inosine } \\
\text { triphosphate } \\
\text { pyrophosphatase }\end{array}$ & ITPA & $\begin{array}{l}\text { Y } \\
\text { (Lean > Fat) }\end{array}$ & $N($ Lean $>$ Fat $)$ & $\begin{array}{l}\text { Pyrophosphatase } \\
\text { activity }\end{array}$ & $\begin{array}{l}\text { Nucleotide } \\
\text { metabolic } \\
\text { process }\end{array}$ \\
\hline & E7 & $\begin{array}{l}\text { PREDICTED: NADH } \\
\text { dehydrogenase } \\
\text { [ubiquinone] } 1 \\
\text { beta subcomplex } \\
\text { subunit } 10\end{array}$ & NDUFB10 & $\begin{array}{l}\text { Y } \\
(\text { Lean }>\text { Fat })\end{array}$ & $N($ Lean $>$ Fat $)$ & $\begin{array}{l}\text { Binding, NADH } \\
\text { dehydrogenase } \\
\text { (quinone) activity }\end{array}$ & $\begin{array}{l}\text { Energy } \\
\text { metabolism }\end{array}$ \\
\hline & E7 & $\begin{array}{l}\text { Nucleoside diphosphate } \\
\text { kinase (protein spot 58) }\end{array}$ & NDK & $\begin{array}{l}\text { Y } \\
\text { (Lean > Fat) }\end{array}$ & N (Lean > Fat) & $\begin{array}{l}\text { Nucleoside } \\
\text { diphosphate } \\
\text { kinase activity }\end{array}$ & $\begin{array}{l}\text { Lipid } \\
\text { transport }\end{array}$ \\
\hline & E12 & $\begin{array}{l}\text { Heat shock } \\
\text { protein beta-1 }\end{array}$ & HSPB1 & $\begin{array}{l}\text { Y } \\
\text { (Lean > Fat) }\end{array}$ & N (Lean > Fat) & $\begin{array}{l}\text { Molecular } \\
\text { chaperone-mediated } \\
\text { protein folding }\end{array}$ & $\begin{array}{l}\text { Lipid } \\
\text { clearance }\end{array}$ \\
\hline \multirow[t]{7}{*}{ Group II-subgroup 2} & E7 & $\begin{array}{l}\text { Nucleoside diphosphate } \\
\text { kinase (protein spot 40) }\end{array}$ & NDK & $\begin{array}{l}\text { Y } \\
\text { (Fat > Lean) }\end{array}$ & N (Lean > Fat) & $\begin{array}{l}\text { Nucleoside } \\
\text { diphosphate } \\
\text { kinase activity }\end{array}$ & $\begin{array}{l}\text { Lipid } \\
\text { transport }\end{array}$ \\
\hline & E7 & $\begin{array}{l}\text { Succinate dehydrogenase } \\
\text { [ubiquinone] flavoprotein } \\
\text { subunit, mitochondrial }\end{array}$ & SDHA & $\begin{array}{l}\text { Y } \\
\text { (Fat }>\text { Lean) }\end{array}$ & N (Lean > Fat) & $\begin{array}{l}\text { Adenyl nucleotide } \\
\text { binding, succinate } \\
\text { dehydrogenase activity }\end{array}$ & $\begin{array}{l}\text { Energy } \\
\text { metabolism }\end{array}$ \\
\hline & E7 & $\begin{array}{l}\text { Heat shock } \\
\text { protein beta-1 }\end{array}$ & HSPB1 & $\begin{array}{l}\text { Y } \\
\text { (Lean > Fat) }\end{array}$ & N (Fat > Lean) & $\begin{array}{l}\text { Molecular chaperone- } \\
\text { mediated protein folding }\end{array}$ & $\begin{array}{l}\text { Lipid } \\
\text { clearance }\end{array}$ \\
\hline & E12 & Sulfotransferase & SULT & $\begin{array}{l}\text { Y } \\
\text { (Lean > Fat) }\end{array}$ & N (Fat > Lean) & $\begin{array}{l}\text { Sulfotransferase activity, } \\
\text { transferase activity }\end{array}$ & $\begin{array}{l}\text { Sulfuryl } \\
\text { transfer }\end{array}$ \\
\hline & E14 & Coronin-1C & COROIC & $\begin{array}{l}\text { Y } \\
(\text { Lean }>\text { Fat })\end{array}$ & $N($ Fat> Lean) & $\begin{array}{l}\text { Cytoskeletal } \\
\text { protein binding }\end{array}$ & $\begin{array}{l}\text { Actin } \\
\text { cytoskeleton } \\
\text { organization }\end{array}$ \\
\hline & E17 & Apolipoprotein A-I & ApoA-I & $\begin{array}{l}\text { Y } \\
(\text { Lean }>\text { Fat })\end{array}$ & N (Fat > Lean) & $\begin{array}{l}\text { Cholesterol binding, } \\
\text { cholesterol transporter activity }\end{array}$ & $\begin{array}{l}\text { Lipid } \\
\text { transport }\end{array}$ \\
\hline & E21 & $\begin{array}{l}\text { Nucleoside } \\
\text { diphosphate kinase } \\
\text { (protein spot 40) }\end{array}$ & NDK & $\begin{array}{l}\text { Y } \\
\text { (Fat }>\text { Lean) }\end{array}$ & N (Lean > Fat) & $\begin{array}{l}\text { Nucleoside diphosphate } \\
\text { kinase activity }\end{array}$ & Lipid transport \\
\hline
\end{tabular}

$\mathrm{Y}$ and $\mathrm{N}$ represent yes and no, respectively

both transcriptional and protein expression levels of HSPB1 agreed with each other. But at E7, the protein level of HSPB1 was opposite to its transcriptional level, which may be due to post-translational modification [29]. HSPB1 (also known as HSP27) serves as an ATPindependent chaperone [30]. In mammals, it has been reported that obese subjects had higher anti-HSP27 antibody levels [31], and induction of HSP27 may blunt the adverse effect of fat overexposure on insulin function
[32]. In diabetic hearts, the phosphorylation of HSP27 enhanced lipoprotein lipase activity and promoted hydrolysis of triglyceride-rich lipoproteins to fatty acids [33]. Phosphorylated HSP27 promotes autophagy and hepatic lipid clearance via autophagy-lysosome pathway in human hepatic cells [34]. We previously found that HSP27 protein was down-regulated in the abdominal adipose tissue of fat birds [12, 13], and here we found that HSP27 was down-regulated in the liver tissue of fat 
birds at E7 and E12. Taken together, our data strongly suggest that HSP27 might be important for hepatic lipid metabolism in chickens.

We identified also 2 other proteins, SULT and TXNDC5, potentially important for lipid metabolism in chicken embryos. The protein and transcriptional abundance of SULT was all higher in the lean line at E7, whereas the protein level of SULT was opposite to its transcriptional level at E12. In humans, SULT shows nuclear translocation and can be post-translationally modified [35]. The different expression patterns of SULT in protein and transcription levels could also be due to post-translational modification at E12 [35]. Sulfotransferase is a transferase enzyme known to catalyze the transfer of a sulfo group from a donor molecule to an acceptor group of numerous substrates [36], and reactive groups for a sulfonation via sulfotransferases may be part of a protein, lipid, or steroid [37]. It is capable of responding to inflammatory cues and controlling lipid metabolism by PPARY in humans [38]. The different expression of SULT between the two lines at E7 and E12 showed that SULT may participate in hepatic lipid metabolism via PPARy in the chicken. Both transcriptional and protein expression levels of TXNDC5 was higher in the fat chickens at E7. TXNDC5 has a protein disulphide isomerase-like domain, and belongs to the thioredoxin family, which is thought to catalyze disulphide formation to aid protein folding or to regulate protein function against endoplasmic reticulum stress induced by oxidative insults. TXNDC5 protein and mRNA levels were significantly associated with hepatic fat content in $A p o E$ knockout mice [39]. TXNDC5 modulated adiponectin signalling by interacting with adiponectin receptor 1 (AdipoR1) [40] and contributed to increased risk of hepatocellular carcinoma development [41]. Moreover, we found also that proteins in the oxidative stress pathway were differentially expressed. Oxidative stress can alter the expression of $A p o B$, and VLDL secretion [42]. Therefore, TXNDC5 could couple with the control of $A p o B$ levels by the oxidative stress pathway, to exert its effect on subsequent hepatic lipid metabolism.

Succinate dehydrogenase (SDH) and NDUFB10 could participate in energy metabolism. The protein abundance of SDHA was higher in the fat line, whereas the protein level was opposite to its transcriptional level at E7. The mRNA and protein levels of NDUFB10 were higher in the lean lines at E7. SDH is known as succinate-ubiquinone oxidoreductase, a complex of the mitochondrial respiratory chain. The complex is composed of four nuclear-encoded subunits (SDHA, SDHB, SDHC and SDHD). It has a role in citric acid cycle and mitochondrial energy generation in mammals [43]. NDUFB10 is a subunit of the NADH dehydrogenase (ubiquinone) complex, located in the mitochondrial inner membrane [44]. The different expression of SDHA and NDUFB10 indicated that the fat birds and lean birds had differences in regard to energy metabolism.

We found two Aminoacyl-tRNA synthetases (KARS and YARS), which are important for amino acid synthesis, were differentially expressed between the fat and lean birds in liver tissue at E7. Both the protein and mRNA expression levels of YARS were significantly higher in the fat birds at E7. The protein level of KARS was significantly higher in the fat birds at E7 and the mRNA level was significantly higher in the lean birds at E7. They catalyze the aminoacylation of tRNA by their cognate amino acid [45]. A number of studies reported that the functions of ARSs were also associated with RNA splicing, immune responses, angiogenesis and cell fate determination besides protein synthesis [46]. But the functions of the two proteins in chicken hepatic lipid metabolism are not very clear.

Two proteins (ITPA, CORO1C) were found to be differentially expressed between the two lines at E17 and E14, respectively. ITPA had higher protein and mRNA abundances in the lean broilers at E7. The protein abundance of CORO1C was significantly higher in the lean broilers at E14, whereas transcriptional abundance was higher in the fat broilers. However, their functions on lipid metabolism remain to be investigated.

In poultry, fat deposition depends on the availability of plasma triglycerides, which are transported as components of lipoproteins [9]. Fattening therefore is in connection with three aspects of lipid metabolism: (1) lipid synthesis; (2) lipid transport; and (3) lipid utilization. It is reported previously that the liver of the avian embryo has the capacity for lipoprotein synthesis, secretion and $\beta$-oxidation [47], though lipogenesis within the embryonic liver tissue is low [48]. Moreover, the chick embryo liver has a very high capacity for $\beta$-oxidation, and fatty acid oxidation provides most of the energy that is required for embryo development [49]. As mentioned above, we found that genes/proteins related to lipid transport and energy metabolism were differentially expressed in the embryonic liver between the fat and lean lines. As a result, differences of transport and utilization of lipids as well, will appear. This could be one of the underlying reasons for the significant difference of fat deposition between our two chicken lines, starting at 7 days posthatch [50].

\section{Conclusions}

Molecular differences related to lipid transport, lipid clearance and energy metabolism exist for hepatic lipid metabolism at embryonic stages between the fat and lean chicken lines, which might contribute to the striking differences of abdominal fat deposition at post-hatch stages. 


\section{Methods}

\section{Chicken embryos}

The fertilized chicken eggs were chosen from the 14th generation of Northeast Agricultural University broiler lines divergently selected for high and low abdominal fat content (NEAUHLF), 200 each for the fat and lean lines, respectively. The fertilized chicken eggs were all hatched in the same conditions at Northeast Agricultural University hatchery.

\section{Collection of liver tissues}

Liver tissues were collected from chicken embryos at the five embryonic stages, E7, E12, E14, E17 and E21. The start of the incubation period was referred to as "E1" (1day-old embryos) and "E21", for newly hatched birds. Liver tissues were collected from chicken embryos under aseptic conditions, frozen immediately in liquid nitrogen, and stored at $-80{ }^{\circ} \mathrm{C}$.

\section{RNA sample preparation and digital gene expression}

Except 30 liver samples from embryos at E7 were pooled together for RNA extraction, for the remaining four embryonic stages, 15 samples were used, respectively. Total RNAs from the 10 samples were extracted using Trizol (Invitrogen), and RNA quality and concentration were evaluated, to ensure RNA integrity number $($ RIN $) \geq 9$.

Sequencing libraries for digital gene expression analyses were prepared according to the following procedures. Messenger RNAs were purified from $6 \mu \mathrm{g}$ total RNA, and reversely transcribed into cDNA, which was then digested using the restriction enzyme NlaIII (recognition sites: $5^{\prime}$-...CATG/GTAC...-3'). Adapter 1 (Illumina) was then ligated to the $5^{\prime}$-end, and the restriction enzyme MmeI was then added, which can recognize the nucleotide sequences composed of adapter 1 and CATG, and then cut at the downstream 17 bp site, to produce tags labelled with adapter 1 . Then adapter 2 (Illumina) was ligated with these tags, and 15 cycles of PCR were performed. PCR products were run on $6 \%$ TBE PAGE and purified, which were then submitted to Illumina $\mathrm{HiSeq}^{\mathrm{TM}} 2000$ for digital gene expression analysis (BGI, Shengzhen).

\section{Bioinformatics analyses of sequencing data}

Procedures for analyzing the digital gene expression profiling data were briefly described as follows. Short reads generated were assessed first for their sequence quality and reads of poor quality were discarded. Libraries containing all possible indices were built. Assessment of sequencing quality was performed, such as distribution of distinct tags (Additional file 8), and proportion of clean tags (all $>96 \%$ ) (Additional file 9). Reference tag library was created by analyzing mRNAs containing the restriction enzyme NlaIII recognition sites (CATG) and 17 bases of the reference gene sequences, which was then used for the alignment of generated short reads, with only one base mismatch allowed. Unambiguous tags mapped to one gene were annotated and novel transcripts were discovered by comparing to known transcripts in the database. Number of genes and its relationship with the sequencing volume was evaluated (2 $\mathrm{M}$ required to identify maximum number of genes, and all 10 libraries > $3 \mathrm{M}$ ) (Additional file 10). Annotated genes and their expression levels were determined and used for downstream differential expression and gene pathway analyses. All genes expressed at a level centred around 10 TPM (transcripts per million clean tags). Furthermore, antisense transcripts were also found, but without significant differences in numbers between lines (Additional file 11). Differentially expressed genes were identified according to the methods described previously [51], and false discovery rate was used for multiple testing correction. We used a criteria of FDR $\leq 0.001$ and fold changes $\geq 2$. $\mathrm{GO}$ and pathway enrichment analysis was performed by using the GO database (http://www.geneontology. org/) [52] and the KEGG pathway (http://www.genome.jp/kegg/) [53].

\section{Protein sample preparation and 2-D DIGE}

There were three replicates for samples at each stage, and each replicate contained a mixture of liver tissues from more than five different animals, respectively. Total proteins were extracted from liver tissues using Trizol (Invitrogen, Carlsbad, CA) according to the manufacturer's protocol with minor modifications as follows. The liver tissue samples were dissolved in lysis buffer containing $7 \mathrm{M}$ urea, $2 \mathrm{M}$ thiourea, 4\% CHAPS, $10 \mathrm{mM}$ Tris $(\mathrm{pH} 8.5)$ and $1 \times$ protease inhibitor cocktails (Roche Diagnostics $\mathrm{GmbH}$, Mannheim, Germany). Then, to remove insoluble materials, samples were centrifuged at $25,000 \mathrm{~g}$ for $30 \mathrm{~min}$. Total proteins were purified by 2D Clean-Up Kit (GE Healthcare, Chalfont St Giles, UK), and protein concentration was determined by 2D Quant Kit (Amersham Biosciences Corp., Piscataway, NJ). Protein stock solutions were kept at a final concentration of $5 \mathrm{mg} / \mathrm{mL}$. We compared and analyzed 30 samples on a total of 15 gels (two samples on one gel). Details of the experimental design were briefly described as follows. Protein samples labeled with Cy3 or Cy5 fluorescent dyes were loaded on the same gel, together with an internal standard labeled with Cy2. The labeling reaction was carried out using $400 \mathrm{pmol}$ dyes for $50 \mu \mathrm{g}$ protein, according to the manufacturer's instructions (GE Healthcare). Each sample was labeled three times to minimize the influence of dye and systematic errors. Then, samples labeled with three different dyes were 
mixed, and an equal volume of $2 \times$ sample buffer $(7 \mathrm{M}$ urea, $2 \mathrm{M}$ thiourea, $4 \%$ CHAPS, $50 \mathrm{mM}$ DTT, $2 \%$ pharmalytes 3-10 NL) were added. Final sample volume was brought to $350 \mu \mathrm{L}$, with additional sample dissolved in a rehydration buffer (7 M urea, $2 \mathrm{M}$ thiourea, 2\% CHAPS, $2 \%$ pharmalytes 3-10 NL, $20 \mathrm{mM}$ DTT). Firstdimension electrophoresis was conducted with the IPGphor3 isoelectric focusing system (GE Healthcare) using IPG strips $(18 \mathrm{~cm}, \mathrm{pH} 3-10 \mathrm{NL})$, with a total focusing time of $8 \mathrm{kVh}$ at $20{ }^{\circ} \mathrm{C}$. Prior to SDS-PAGE, each strip was equilibrated with $15 \mathrm{~mL}$ equilibration buffer A (6 M urea, $50 \mathrm{mM}$ Tris- $\mathrm{HCl}, \mathrm{pH} 8.8,30 \%$ glycerol, $2 \%$ SDS, 0. 002\% Bromophenol blue, $10 \mathrm{mM}$ DTT) on a rocking table for $15 \mathrm{~min}$, followed by a treatment of another $15 \mathrm{~min}$ in $15 \mathrm{~mL}$ equilibration buffer $\mathrm{B}$ (6 M urea, $50 \mathrm{mM}$ Tris- $\mathrm{HCl}, \mathrm{pH} 8.8,30 \%$ glycerol, $2 \%$ SDS, $0.002 \%$ bromophenol blue, $25 \mathrm{mg} / \mathrm{mL}$ iodoacetamide). The strips were then loaded onto the $12.5 \%$ acrylamide gels, and gels were run under a constant power at $12{ }^{\circ} \mathrm{C}$ first with $2 \mathrm{~W} /$ strip for $60 \mathrm{~min}$, and then $15 \mathrm{~W} /$ strip, until the bromophenol blue reached the bottoms of the gels.

\section{Scanning and image analysis}

Gels were scanned by the Typhoon 9400 scanner (GE Healthcare). Cy2, Cy3, and Cy5 images for each gel were taken at 488/520, 532/580 and 633/670 nm excitation/ emission wavelengths, respectively, adjusting the pixel resolution to $100 \mathrm{~mm}$. All gels were scanned at $50 \mathrm{~nm}$ resolution, and the intensity was adjusted to ensure that the maximum volume of each image was within 50,00080,000 . Images were cropped to remove areas extraneous to the gel image, using Image Quant V 5.2 (Amersham Biosciences, UK). Image analysis was performed with DeCyder 6.5 (GE Healthcare). The DeCyder BVA module was used to performing comparative cross-gel statistical analysis of all spots, permitting the detection of differentially expressed spots between experimental groups (t-test, $P<0.05)$. Protein spots with a fold change of at least 1.5 were analyzed.

\section{Spot picking and in-gel digestion}

Gels were fixed and stained with Coomassie brilliant blue (CBB). Proteins of interests, as defined by the $2 \mathrm{D}$ DIGE/DeCyder analysis, were excised from the CBBstained gels. Gel pieces were added into $100 \mathrm{mmol} / \mathrm{L}$ $\mathrm{NH}_{4} \mathrm{HCO}_{3}$ solution buffer in $30 \%$ acetonitrile, to decolor for $15 \mathrm{~min}$. The precipitate was collected and washed in $100 \%$ acetonitrile and put aside at room temperature for $5 \mathrm{~min}$. After vacuum drying, the gel pieces were incubated with modified trypsin (sequencing grade) at a final concentration of $50 \mathrm{ng} / \mathrm{uL}$ at $4{ }^{\circ} \mathrm{C}$ for $60 \mathrm{~min}$, and then treated in $50 \mathrm{mmol} / \mathrm{L} \mathrm{NH}_{4} \mathrm{HCO}_{3}$ for $16 \mathrm{~h}$ at $37{ }^{\circ} \mathrm{C}$. Digested peptide mixtures were extracted twice with 0 . $1 \%$ TFA in $60 \%$ acetonitrile. Then, the extracted solutions were blended, lyophilized and kept at $-20{ }^{\circ} \mathrm{C}$ for further identification by MS.

\section{MALDI-TOF-TOF MS analysis and database search}

For MALDI-TOF-TOF MS analysis, $1 \mathrm{uL}$ of sample was mixed with $1 \mathrm{uL}$ of matrix and loaded onto the MALDITOF slides, and the spot number and sample name were recorded. MALDI-TOF-TOF MS analysis was performed on a 4800 Plus MALDI-TOF-TOF ${ }^{\mathrm{m} x}$ analyzer (Applied Biosystems, Foster City, CA, USA). The obtained spectra of proteins were submitted for online database searching against NCBInr and Swiss-Prot databases, using MASCOT program (http://www.matrixscience.com). The following parameters were adopted when searching protein databases: $0.1 \mathrm{Da}$ mass tolerance for peptides and $0.3 \mathrm{Da}$ mass tolerance of TOF-TOF fragments, allowed $50 \mathrm{ppm}$ mass outlier error, reduced Min $\mathrm{S} / \mathrm{N}$ to 20 . Only significant hits were accepted, as defined by the MASCOT probability analysis $(P<0.05)$. Positive hits with either protein score confidence interval (CI) \% or Ion $\mathrm{CI} \%$ greater than 95 were considered significant. GO analysis was performed by using the GO database (http://www. geneontology.org/) [52].

\section{qRT-PCR}

Liver samples were prepared as aforementioned. For E7, at least 15 liver samples were combined into one biological replicate. For E12 and E14, 5 liver samples were mixed together. For E17 and E21, only were 3 liver samples grouped together. Three biological replicates were assayed for the validation of 12 DEGs, while three (E7 and E12), four (E14 and E17), and five (E21) biological replicates were assayed for 12 DEPs, respectively. Primers were designed to span introns and the sequences were listed as in Additional file 12.

Total RNA of liver tissues (50-100 mg) was isolated using Trizol (Invitrogen, Carlsbad, California) according to the manufacturer's recommendations. RNA concentration was determined by spectrophotometry, and RNA quality was checked on $1.5 \%$ agarose gel. cDNAs were reverse transcribed from $1 \mu \mathrm{g}$ of total RNA at $25^{\circ} \mathrm{C}$ for $5 \mathrm{~min}, 42{ }^{\circ} \mathrm{C}$ for $60 \mathrm{~min}$, and $70{ }^{\circ} \mathrm{C}$ for $15 \mathrm{~min}$, using 0 . $5 \mu \mathrm{L}$ an oligo(dT) primer (Takara, Daliang, China), and $1.0 \mu \mathrm{L}$ ImProm-II reverse transcriptase (Promega, Madison, WI) in a final volume of $20 \mu \mathrm{L}$. TATA box-binding protein $(T B P)$ was used as an internal reference to normalize the expression data.

qRT-PCR reactions were performed using FastStart Universal SYBR Green Master kit (Roche) on QuantStudio $^{\text {Tw }}$ Real-time PCR System following cycling conditions: 1 cycle at $50{ }^{\circ} \mathrm{C}$ for $2 \mathrm{~min}$ and $95^{\circ} \mathrm{C}$ for $10 \mathrm{~min}, 40$ cycles at $95{ }^{\circ} \mathrm{C}$ for $15 \mathrm{~s}$ and $60{ }^{\circ} \mathrm{C}$ for $1 \mathrm{~min}$, and a melting curve analysis $\left(95^{\circ} \mathrm{C}\right.$ for $15 \mathrm{~s}, 60{ }^{\circ} \mathrm{C}$ for $1 \mathrm{~min}$ and $95^{\circ} \mathrm{C}$ for $30 \mathrm{~s}$ ). Relative expression levels were calculated using 
the $2^{-\Delta \mathrm{Ct}}$ method [54]. Data were analyzed using the Ttest and $p$-value $<0.05$ was considered to be significant.

\section{Western blot}

Liver samples used in qRT-PCR at E17 were homogenized in Radio Immunoprecipitation Assay (RIPA) buffer (50 mM Tris, PH 7.4, $150 \mathrm{mM} \mathrm{NaCl,} \%$ Triton X-100, $1 \%$ sodium deoxycholate, $0.1 \%$ SDS) with $10 \mathrm{mM}$ of a protease inhibitor Phenylmethanesulfonyl fluoride, and centrifuged at $13,000 \times g$ for $10 \mathrm{~min}$. The total protein samples were separated by $12 \%$ SDS-PAGE and transferred onto nitrocellulose membranes. After blocking with 5\% nonfat milk in PBS with Tween-20 (PBST) for $2 \mathrm{~h}$ at room temperature, the membranes were incubated with antibodies against ApoA-I (1:800 dilution; Abmart, Shanghai, China), FABP2 (1:800 dilution; Santa Cruz, Dallas, USA) or $\beta$-actin (1:1000 dilution; TransGen, Beijing, China) overnight at $4{ }^{\circ} \mathrm{C}$. The rabbit antichicken ApoA-I antibody was prepared in our lab. Then, the membranes were washed with PBST for five times and incubated with goat anti-rabbit or goat anti-mouse conjugated with horseradish peroxide (1:5000 dilution; Beyotime, Beijing, China) for $1 \mathrm{~h}$ at room temperature. Following five washes with PBST, signals were tested using super ECL kit (HaiGene, Harbin, China). Densitometric measurement of the bands was analyzed using a laboratory imaging and analysis system (lane 1D), and then $t$-test was used for the statistical significance analysis.

\section{Additional files}

Additional file 1: Figure S1. Number of genes expressed and novel transcripts. $L$ and $F$ represent the lean and fat chicken lines, respectively. (DOC $177 \mathrm{~kb}$ )

Additional file 2: Table S1. DEGs identified in liver of E7 embryos between the fat and lean lines. Rawlntensity, raw copy number of tag; TPM, normalized expression of tag; log2 Ratio, log2 (fold changes of differentially expressed genes); FDR, false-discovery rate. (XLSX $72 \mathrm{~kb}$ )

Additional file 3: Table S2. DEGs identified in liver of E12 embryos between the fat and lean lines. (XLSX $27 \mathrm{~kb}$ )

Additional file 4: Table S3. DEGs identified in liver of E14 embryos between the fat and lean lines. (XLSX $125 \mathrm{~kb}$ )

Additional file 5: Table S4. DEGs identified in liver of E17 embryos between the fat and lean lines. (XLSX $138 \mathrm{~kb}$ )

Additional file 6: Table S5. DEGs identified in liver of E21 embryos between the fat and lean lines. (XLSX $31 \mathrm{~kb}$ )

Additional file 7: Figure S2. Protein profiling on liver tissues of chicken embryos. A total of 15 gels were assayed, and each gel contained three samples. Samples from the lean and fat chicken lines were labeled with Cy3 and Cy5, respectively. A pooled sample was used as the internal standard, labeled with Cy2. (DOC $4823 \mathrm{~kb}$ )

Additional file 8: Figure S3. Distribution of distinct tags. "Tags Containing N", tags containing unknown bases; "Only adaptors", reads containing only the adaptor sequence; "Copy Number $<2$ ", tags whose copy number is less than 2; "Clean tags", tags remained after quality control and used for downstream analysis. $L$ and $F$ represent the lean and fat chicken lines, respectively. (DOC $176 \mathrm{~kb}$ )
Additional file 9: Figure S4. Proportion of clean tag numbers (> 96\%). L and $\mathrm{F}$ represent the lean and fat chicken lines, respectively. (DOC $166 \mathrm{~kb}$ )

Additional file 10: Figure S5. Relationship of library size with percentage of genes identified. (DOC $64 \mathrm{~kb}$ )

Additional file 11: Figure S6. Number of antisense transcripts. $L$ and $F$ represent the lean and fat chicken lines, respectively. (DOC $144 \mathrm{~kb}$ )

Additional file 12: Table S6. Primer sequences used for qRT-PCR. (DOC $43 \mathrm{~kb}$ )

\section{Abbreviations}

ACADL: Long-chain acyl-coenzyme A dehydrogenase; ACSBG2: Acyl-CoA synthetase bubblegum family member 2; AdipoR1: Adiponectin receptor 1; AFABP: Adipocyte fatty acid-binding protein; AFP: Abdominal fat percentage; ALDH7A1: Aldehyde dehydrogenase 7 family member A1;

APOA4: Apolipoprotein A4; ApoA-l: Apolipoprotein A-l; ApoB: Apolipoprotein B; ApoE: Apolipoprotein E; BAP1: BRCA1 associated protein 1;

CORO1C: Coronin-1C; DEGs: Differentially expressed genes;

DEPs: Differentially expressed proteins; E12: Embryonic day 12;

E14: Embryonic day 14; E17: Embryonic day 17; E21: Day 1 after hatch;

E7: Embryonic day 7; FABP2: Fatty acid-binding protein, intestinal; GO: Gene ontology; HDL: High-density lipoprotein; HSPA9: Heat shock 70 kDa protein 9; HSPB1: Heat shock protein beta-1; IL8: Interleukin 8-like 2; ITPA: Inosine triphosphatase; KARS: Lysyl-tRNA synthetase; LBFABP: Liver basic fatty acids binding protein; LPL: Lipoprotein lipase; MTMR9: Myotubularin related protein 9; NDK: Nucleoside diphosphate kinase; NDUFB10: PREDICTED: NADH dehydrogenase [ubiquinone] 1 beta subcomplex subunit 10;

NEAUHLF: Northeast Agricultural University broiler lines; OVAL: Ovalbumin; PPARY: Peroxisome proliferator-activated receptor gamma; SDHA: Succinate dehydrogenase [ubiquinone] flavoprotein subunit, mitochondrial;

SULT: Sulfotransferase; TBP: TATA box-binding protein; TCA cycle: Citrate cycle; TMEM79: Transmembrane protein 79; TXNDC5: Thioredoxin domaincontaining protein 5; VLDL: Very low-density lipoprotein; XPO5: Exportin 5; YARS: Tyrosyl-tRNA synthetase

\section{Acknowledgements}

The authors thank the members of Poultry Research Group in College of Animal Science and Technology at Northeast Agricultural University for help in hatching eggs and technical support.

\section{Funding}

This study was supported by the National 863 project of China (No. 2013AA102501) and the China Agriculture Research System (No. CARS-41). The funding bodies had no role in the specific design of the current study and collection, analysis and interpretation of data and in writing of the manuscript.

\section{Availability of data and materials}

The digital gene expression data was deposited in Gene Expression Omnibus (GEO) under the accession number GSE101182. Other supporting materials are included as additional files.

\section{Authors' contributions}

WN performed the experiments, analyzed data, drafted and wrote the manuscript. YYW performed the experiments, analyzed data and drafted the manuscript. PFG helped perform the experiments. CYW and BHC participated in the analysis of data. YXW and NW helped design the study. ZQD participated in the analysis of data and helped write the manuscript. $\mathrm{HL}$ designed the study and helped write the manuscript. All authors read and approved the final manuscript.

\section{Ethics approval and consent to participate}

All animal work was conducted following the guidelines for the care and use of experimental animals, established by the Ministry of Science and Technology of the People's Republic of China (Approval number: 2006-398), and also approved by the Laboratory Animal Management Committee of Northeast Agricultural University.

\section{Competing interests}

The authors declare that they have no competing interests. 


\section{Publisher's Note}

Springer Nature remains neutral with regard to jurisdictional claims in published maps and institutional affiliations.

Received: 5 December 2017 Accepted: 10 May 2018

Published online: 23 May 2018

\section{References}

1. Siegel PB. Evolution of the modern broiler and feed efficiency. Annu Rev Anim Biosci. 2014;2:375-85.

2. Godfray HC, Beddington JR, Crute IR, Haddad L, Lawrence D, Muir JF, et al. Food security: the challenge of feeding 9 billion people. Science. 2010;327: 812-8.

3. Dunnington EA, Siegel PB. Long-term divergent selection for eight-week body weight in white Plymouth rock chickens. Poult Sci. 1996;75:1168-79.

4. Kessler AM, Snizek PN Jr, Brugalli I. Manipulação da quantidade de gordura na carcaça de frangos. In: Anais da Conferência APINCO de Ciência e Tecnologia Avícola. Campinas: Brazil Press, APINCO; 2000. p. 107-33.

5. Zerehdaran $\mathrm{S}$, Vereijken $\mathrm{AL}$, van Arendonk JA, van der Waaijt EH. Estimation of genetic parameters for fat deposition and carcass traits in broilers. Poult Sci. 2004;83:521-5

6. Saadoun A, Leclercq B. In vivo lipogenesis of genetically lean and fat chickens: effects of nutritional state and dietary fat. J Nutr. 1987;117:428-35.

7. Leveille GA. In vitro hepatic lipogenesis in the hen and chick. Comp Biochem Physiol. 1969;28:431-5.

8. Alvarenga RR, Zangeronimo MG, Pereira $\amalg$, Rodrigues PB, Gomide EM. Lipoprotein metabolism in poultry. World Poultry Sci J. 2011;67:431-40.

9. Hermier D. Lipoprotein metabolism and fattening in poultry. J Nutr. 1997. 127(Suppl 5):805-8S.

10. Wang HB, Li H, Wang QG, Zhang XY, Wang SZ, Wang YX, et al. Profiling of chicken adipose tissue gene expression by genome array. BMC Genomics. 2007:8:193.

11. Wang HB, Wang QG, Zhang XY, Gu XF, Wang N, Wu SB, et al. Microarray analysis of genes differentially expressed in the liver of lean and fat chickens. Animal. 2010:4:513-22.

12. Wu CY, Wu YY, Liu CD, Wang YX, Na W, Wang N, et al. Comparative proteome analysis of abdominal adipose tissues between fat and lean broilers. Proteome Sci. 2016;14:9.

13. Wang D, Wang N, Li N, Li H. Identification of differentially expressed proteins in adipose tissue of divergently selected broilers. Poult Sci. 2009;88: 2285-92.

14. Zhang H, Wang SZ, Wang ZP, Da Y, Wang N, Hu XX, et al. A genome-wide scan of selective sweeps in two broiler chicken lines divergently selected for abdominal fat content. BMC Genomics. 2012;13:704.

15. Griffin HD, Guo K, Windsor D, Butterwith SC. Adipose tissue lipogenesis and fat deposition in leaner broiler chickens. J Nutr. 1992;122:363-8.

16. Wang Z, Liu W, Fan G, Zhai X, Zhao Z, Dong Y, et al. Quantitative proteomelevel analysis of paulownia witches' broom disease with methyl methane sulfonate assistance reveals diverse metabolic changes during the infection and recovery processes. PeerJ. 2017:5:e3495.

17. Alpers DH, Bass NM, Engle MJ, DeSchryver-Kecskemeti K. Intestinal fatty acid binding protein may favor differential apical fatty acid binding in the intestine. Biochim Biophys Acta. 2000;1483:352-62.

18. Auinger A, Helwig U, Rubin D, Herrmann J, Jahreis G, Pfeuffer $M$, et al. Human intestinal fatty acid binding protein 2 expression is associated with fat intake and polymorphisms. J Nutr. 2010;140:1411-7.

19. Montoudis A, Seidman E, Boudreau F, Beaulieu JF, Menard D, Elchebly M, et al. Intestinal fatty acid binding protein regulates mitochondrion betaoxidation and cholesterol uptake. J Lipid Res. 2008:49:961-72.

20. De La Rosa A, Williams RL, Steeg PS. Nm23/nucleoside diphosphate kinase: toward a structural and biochemical understanding of its biological functions. BioEssays. 1995;17:53-62.

21. Lacombe ML, Milon L, Munier A, Mehus JG, Lambeth DO. The human Nm23/nucleoside diphosphate kinases. J Bioenerg Biomembr. 2000;32: 247-58

22. Krishnan KS, Rikhy R, Rao S, Shivalkar M, Mosko M, Narayanan R, et al. Nucleoside diphosphate kinase, a source of GTP, is required for dynamindependent synaptic vesicle recycling. Neuron. 2001;30:197-210.

23. Berg JM, Tymoczko JL, Stryer L. Biochemistry. 5th ed. New York: WH Freeman; 2002.
24. Francois-Moutal L, Maniti O, Marcillat O, Granjon T. New insights into lipidnucleoside diphosphate kinase-D interaction mechanism: protein structural changes and membrane reorganisation. Biochim Biophys Acta. 2013;1828: 906-15.

25. Schlattner U, Tokarska-Schlattner M, Ramirez S, Tyurina YY, Amoscato AA, Mohammadyani $\mathrm{D}$, et al. Dual function of mitochondrial Nm23-H4 protein in phosphotransfer and intermembrane lipid transfer: a cardiolipindependent switch. J Biol Chem. 2013;288:111-21.

26. Bhattacharyya N, Chattapadhyay R, Oddoux C, Banerjee D. Characterization of the chicken apolipoprotein A-I gene 5'-flanking region. DNA Cell Biol. 1993:12:597-604.

27. Mooradian AD, Haas MJ, Wong NC. The effect of select nutrients on serum high-density lipoprotein cholesterol and apolipoprotein A-I levels. Endocr Rev. 2006;27:2-16.

28. Ma D, Liu W, Wang Y. ApoA-I or ABCA1 expression suppresses fatty acid synthesis by reducing 27-hydroxycholesterol levels. Biochimie. 2014;103:101-8.

29. Hendric JP, Hartl FU. Molecular chaperone functions of heat-shock proteins. Annu Rev Biochem. 1993;62:349-84.

30. Santoro MG. Heat shock factors and the control of the stress response. Biochem Pharmacol. 2000;59:55-63.

31. Kargari M, Tavassoli S, Avan A, Ebrahimi M, Azarpazhooh MR, Asoodeh R, et al. Relationship between serum anti-heat shock protein 27 antibody levels and obesity. Clin Biochem. 2017:50:690-5.

32. McCarty MF. Induction of heat shock proteins may combat insulin resistance. Med Hypotheses. 2006;66:527-34.

33. Kim MS, Kewalramani G, Puthanveetil P, Lee V, Kumar U, An D, et al. Acute diabetes moderates trafficking of cardiac lipoprotein lipase through p38 mitogen-activated protein kinase-dependent actin cytoskeleton organization. Diabetes. 2008:57:64-76.

34. Shen L, Qi Z, Zhu Y, Song X, Xuan C, Ben $P$, et al. Phosphorylated heat shock protein 27 promotes lipid clearance in hepatic cells through interacting with STAT3 and activating autophagy. Cell Signal. 2016;28: 1086-98

35. He D, Falany CN. Characterization of proline-serine-rich carboxy terminus in human sulfotransferase 2B1b: immunogenicity, subcellular localization, kinetic properties, and phosphorylation. Drug Metab Dispos. 2006;34:1749-55

36. Negishi M, Pedersen LG, Petrotchenko E, Shevtsov S, Gorokhov A, Kakuta Y, et al. Structure and function of sulfotransferases. Arch Biochem Biophys. 2001;390:149-57.

37. Rath VL, Verdugo D, Hemmerich S. Sulfotransferase structural biology and inhibitor discovery. Drug Discov Today. 2004;9:1003-11.

38. Xu Y, Yang X, Wang Z, Li M, Ning Y, Chen S, et al. Estrogen sulfotransferase (SULT1E1) regulates inflammatory response and lipid metabolism of human endothelial cells via PPARy. Mol Cell Endocrinol. 2013;369:140-9.

39. Ramírez-Torres A, Barceló-Batllori S, Martínez-Beamonte R, Navarro MA Surra JC, Arnal C, et al. Proteomics and gene expression analyses of squalene-supplemented mice identify microsomal thioredoxin domaincontaining protein 5 changes associated with hepatic steatosis. J Proteome. 2012;77:27-39.

40. Charlton HK, Webster J, Kruger S, Simpson F, Richards AA, Whitehead JP. ERp46 binds to AdipoR1, but not AdipoR2, and modulates adiponectin signalling. Biochem Biophys Res Commun. 2010:392:234-9.

41. Park MS, Kim SK, Shin HP, Lee SM, Chung JH. TXNDC5 gene polymorphism contributes to increased risk of hepatocellular carcinoma in the Korean male population. Anticancer Res. 2013;33:3983-7.

42. Silva M, da Costa Guerra JF, Sampaio AF, de Lima WG, Silva ME, Pedrosa ML. Iron dextran increases hepatic oxidative stress and alters expression of genes related to lipid metabolism contributing to hyperlipidaemia in murine model. Biomed Res Int. 2015:2015:272617.

43. Oyedotun KS, Lemire BD. The quaternary structure of the saccharomyces cerevisiae succinate dehydrogenase. Homology modeling, cofactor docking, and molecular dynamics simulation studies. J Biol Chem. 2004;279:9424-31.

44. Voet D, Voet JG, Pratt CW. Fundamentals of biochemistry: life at the molecular level. 4th ed. Hoboken: Wiley; 2013. p. 581-620.

45. Young HJ, Lee JW, Kim S. Function of membranous lysyl-tRNA synthetase and its implication for tumorigenesis. Biochim Biophys Acta. 2016;1864: 1707-13.

46. Han JM, Kim JY, Kim S. Molecular network and functional implications of macromolecular tRNA synthetase complex. Biochem Biophys Res Commun. 2003;303:985-93. 
47. Speake BK, Murray AM, Noble RC. Transport and transformations of yolk lipids during development of the avian embryo. Prog Lipid Res. 1998; 37:1-32.

48. Noble RC. Lipid metabolism in the chick embryo. Proc Nutr Soc. 1986; 45:17-25.

49. Romanoff AL. Biochemistry of the avian embryo. New York: Macmillan; 1967.

50. Guo L, Sun B, Shang Z, Leng L, Wang Y, Wang N, Li H. Comparison of adipose tissue cellularity in chicken lines divergently selected for fatness. Poult Sci. 2011;90:2024-34.

51. Audic S, Claverie JM. The significance of digital gene expression profiles. Genome Res. 1997;7:986-95.

52. Ashburner M, Ball CA, Blake JA, Botstein D, Butler H, Cherry JM, et al. Gene ontology: tool for the unification of biology. The gene ontology consortium. Nat Genet. 2000;25:25-9.

53. Kanehisa M, Goto S, Sato Y, Furumichi M, Tanabe M. KEGG for integration and interpretation of large-scale molecular data sets. Nucleic Acids Res. 2012:40:D109-14.

54. Schmittgen TD, Livak KJ. Analyzing real-time PCR data by the comparative C(T) method. Nat Protoc. 2008:3:1101-8.

Ready to submit your research? Choose BMC and benefit from:

- fast, convenient online submission

- thorough peer review by experienced researchers in your field

- rapid publication on acceptance

- support for research data, including large and complex data types

- gold Open Access which fosters wider collaboration and increased citations

- maximum visibility for your research: over $100 \mathrm{M}$ website views per year

At BMC, research is always in progress.

Learn more biomedcentral.com/submissions 